\title{
How Personalized Medicine Became Genetic, and Racial: Werner Kalow and the Formations of Pharmacogenetics
}

\section{Citation}

Jones, D. S. 2013. “How Personalized Medicine Became Genetic, and Racial: Werner Kalow and the Formations of Pharmacogenetics." Journal of the History of Medicine and Allied Sciences 68, no. 1: 1-48.

\section{Published Version}

doi:10.1093/jhmas/jrr046

\section{Permanent link}

http://nrs.harvard.edu/urn-3:HUL.InstRepos:12718790

\section{Terms of Use}

This article was downloaded from Harvard University's DASH repository, and is made available under the terms and conditions applicable to Open Access Policy Articles, as set forth at http:// nrs.harvard.edu/urn-3:HUL.InstRepos:dash.current.terms-of-use\#OAP

\section{Share Your Story}

The Harvard community has made this article openly available.

Please share how this access benefits you. Submit a story.

\section{Accessibility}


How Personalized Medicine Became Genetic, and Racial: Werner Kalow and the Formations of Pharmacogenetics

David S. Jones, M.D., Ph.D.

Program in Science, Technology, and Society

Massachusetts Institute of Technology

Department of Global Health and Social Medicine

Harvard Medical School

\section{Contact:}

dsjones@mit.edu

617-256-6255 (o)

$617-258-8118(f)$

77 Massachusetts Avenue, E51-185

Cambridge, MA 02139 


\begin{abstract}
Physicians have long puzzled over a well-known phenomenon: different patients respond differently to the same treatment. Although many explanations exist, pharmacogenetics has now captured the medical imagination. While this might seem part of the broader interest in all things genetic, the early history of pharmacogenetics reveals the specific factors that contributed to the emergence of genetics within pharmacology. This paper examines the work of one pioneering pharmacologist, Werner Kalow, to trace the evolving intellectual formations of pharmacogenetics and, in particular, the focus on race. Working in the 1950s and 1960s, Kalow made three arguments to demonstrate the relevance of genetics to pharmacology, based on laboratory techniques, analogies to differences between other animal species, and appeals to the logic of natural selection. After contributing to the emergence of the field, Kalow maintained his advocacy for pharmacogenetics for four decades, collecting more evidence for its relevance, navigating controversies about race and science, and balancing genetics against other possible explanations of patient variability. Kalow's work demonstrates the deep roots of the genetic and racial preoccupations in pharmacology. Understanding this history can restore attention to other explanations of individuality in medical practice, something of increasing importance given the current interest in personalized medicine.
\end{abstract}

\title{
Keywords:
}

6-10*** 
In 1962 Toronto pharmacologist Werner Kalow published Pharmacogenetics, the first full length treatment given to a new science that explored how genetic traits influenced the safety and effectiveness of medications. ${ }^{1}$ When he presented his work at the New York Academy of Sciences that October, the New York Times ran both an article and an editorial about his findings. ${ }^{2}$ Kalow's book drew interest at the time because it offered an explanation for something that increasingly vexed physicians. Physicians had known and expected for millennia that different people responded differently to their ministrations. Skilled physicians tailored both diagnosis and therapy to each patient. With the rise of laboratory medicine in the late nineteenth century, however, standardized diagnosis and treatment increasingly became the goal of medical thought and practice. Patients' bodies did not cooperate: idiosyncratic reactions often accompanied the introduction of new drugs. ${ }^{3}$ Even as physicians achieved unprecedented pharmacological capabilities in the decades after World War II, their actual experience with treatment outcomes forced them to re-engage with the puzzle of patient variability. How could it be explained? How could these explanations be used to optimize the safety and efficacy of medicine?

In the fifty years since Kalow published his book, genetics has come to dominate the answers to these questions. For instance, when Francis Collins and Margaret Hamburg, the heads of the National Institutes of Health and the Food and Drug Administration, described their vision for "personalized medicine," their 
concerns were exclusively genetic. ${ }^{4}$ It is tempting to see pharmacogenetics simply as one of many examples of the current popularity of all things genetic. ${ }^{5}$ Its actual emergence, however, was the result of deliberate strategies to demonstrate the existence and relevance of genetic determinants of drug response. When physicians and researchers began to focus on the puzzle of individual variation in drug response in the late 1940s, they had recognized three basic modes of explanation: heredity, environment, and behavior. Kalow's work demonstrates how one influential researcher made the case that one of these factors -- genetics -deserved special attention.

Kalow did not rely on traditional techniques of genetic analysis that traced traits across families in order to demonstrate their inheritance. Instead, he developed three different kinds of arguments. First, he used new techniques of pharmacology and enzyme biochemistry, especially spectrophotometry, to quantify pharmacological individuality in ways that made difference legible, and eventually genetic. Second, he drew analogies between drug reactions in humans and other animal species: pharmacologists' use of a menagerie of animal models provided an influential precedent for thinking about differences between individuals and between species. Third, he appealed to the logic of natural selection and wove pharmacologists' findings into evolutionary narratives that justified the existence and relevance of individual difference. These last two arguments, in turn, introduced race into pharmacogenetics and forced pharmacologists to engage with 
the politics of race and science, a move with consequences that remain relevant today.

Kalow was not the only person responsible for the emergence of pharmacogenetics in the 1950s, nor was he the only person to make these sorts of arguments. He did, however, play a central role in the consolidation of pharmacogenetics as a specific field. ${ }^{6}$ Despite this, he has received no serious attention from historians of medicine or science. ${ }^{7}$ Anthropologists and sociologists, who have studied pharmacogenomics, ${ }^{8}$ have focused on developments since the 1990s. ${ }^{9}$ This paper offers a partial solution to this gap. By recovering Kalow's history, it offers insight into the interests and strategies that influenced the emergence of pharmacogenetics. And since his career spanned six decades, from its origins in post-war Berlin until his death in 2008, it also reveals important aspects of the subsequent development of the field. Two issues are especially relevant.

First, Kalow's work over his long career shows how race emerged as a central concern at the origins of the field and has remained an irresistible attraction for pharmacologists. This persistent presence offers a warning to current researchers who dismiss concerns about race and medicine by arguing that racebased prescribing is simply a passing phase on the road to a fully personalized medicine. Second, the current preeminence of pharmacogenetics was not foreordained. Although Kalow and the New York Times had been impressed with pharmacogenetics in 1962, the field made slow progress and remained on the 
margins of medical science into the 1990s. Other researchers looked to other determinants of drug response, especially the impact of food and environmental toxins, and increasingly the problem of non-compliance. The choices that researchers made about which explanations to emphasize shed light on how their values and interests shaped the contingent development of a scientific field. ${ }^{10}$ An appreciation of the complexity of this history offers models for physicians and scholars today interested in recovering other ways to personalize medicine.

\section{An Accidental Pharmacogeneticist}

In 1947, amid the chaos of post-war Berlin, two patients died after receiving routine doses of procaine [Novocain], a topical anesthetic. Hans Herken, a professor of pharmacology at the University of Berlin, suspected that endemic malnutrition in the devastated city had left the patients with a deficiency of a crucial metabolic enzyme. But he had no proof. He assigned the problem to a young pharmacologist, Werner Kalow. ${ }^{11}$

Kalow had never intended to become a pharmacologist. As a medical student in Germany and Austria in the late 1930s, he had dabbled in research -- for instance, conducting bird surveys on the Baltic coast in the summer of 1937. Drafted into the German Navy in 1938, he was allowed to complete his medical studies. He submitted his thesis, on the effects of adrenal extracts on blood pressure, in 1941. While interning at a naval hospital in South Holland in 1942, he inadvertently insulted a visiting German admiral. The admiral promptly assigned 
him to be the ship surgeon on a blockade runner, a degrading and dangerous assignment. After several nearly catastrophic attacks by allied bombers, the ship escaped European waters and delivered its cargo, a hydroelectric generator, to Japan. $^{12}$

The return trip did not go as well. The Allied blockade of Europe stranded the crew in the Japanese Empire until 1944. Then a United States destroyer sunk the ship off the coast of Brazil and took the crew as prisoners of war. Kalow ended up at a large POW camp, Papago Park, near Phoenix, Arizona. This proved to be a blessing. Since the war had left stateside hospitals short-staffed, the Army recruited Kalow to work as an intern, allowing him to complete his medical training while a POW. When he returned to Germany in 1946, he tried his hand at clinical work. He quickly decided to seek a career in research instead. His choice of specialty was a political one. Most of the University of Berlin, including the Pathology Department, had ended up in the Russian sector. The Pharmacology Department, however, had been bombed during the war and was rebuilt in the American sector. Kalow chose to stick with the Americans and become a pharmacologist. He began his work in January $1947 .^{13}$

Kalow's initial work took up a basic question in pharmacology: what happens to a drug when it enters the body. He completed a study of one poison, phenylethanolamine. ${ }^{14}$ When the two patients mentioned above died after a typical dose of procaine, Herken asked Kalow to figure out what had happened. Researchers in the United States, led by Bernard Brodie, had recently identified a 
specific enzyme, procaine esterase, that metabolized this drug. Had malnutrition somehow altered its function? Kalow performed studies on human serum to find out. $^{15}$

The work was difficult. Kalow had no way to measure directly the level of an enzyme in serum. He could, however, measure drug levels with a spectrophotometer. ${ }^{16}$ With this device, he could shine a light on a sample and analyze the absorption spectrum. As an enzyme metabolized the drug, the concentration fell and the absorption spectrum changed. The rate of change of concentration correlated with the level of enzyme activity. However, to do this Kalow needed a roomful of equipment, including a photomultiplier tube donated by the U.S. Army, and a physicist to generate the needed wavelengths of ultraviolet radiation. ${ }^{17}$ Kalow persevered with the device and his work caught the attention of a delegation of visiting American scientists. One offered him a fellowship at the University of Pennsylvania, where he joined a team working on cardiac physiology. ${ }^{18}$

On arriving in Philadelphia in late 1949, Kalow found a new device, a Beckman DU Quartz Spectrophotometer. ${ }^{19}$ This desktop box could do on its own what had required a roomful of equipment and a physicist in Berlin. Able to work more quickly, Kalow showed that one enzyme, serum cholinesterase, metabolized many local anesthetics, including procaine and dibucaine, as well as acetylcholine. ${ }^{20}$ Tutored in enzyme biochemistry by Britton Chance, Kalow conducted sophisticated studies of enzyme competition and inhibition. Reaction 
rates depended on how tightly enzymes bound their substrates. This, in turn, depended on enzyme structure. ${ }^{21}$

Offered a faculty position in the Department of Pharmacology at the University of Toronto in 1951, and eager to avoid being drafted a second time-this time into the United States Army for the Korean War -- Kalow moved once more. He worked on a variety of projects at first. One project, conducted with the Toronto police, used a Harger Drunkometer to quantify alcohol levels in intoxicated drivers after accidents. ${ }^{22}$ He also continued his more traditional work in pharmacology and used a spectrophotometer to study curare and procaine. ${ }^{23}$ Kalow soon returned to his true passion, cholinesterase. During the war, a Toronto team had used a cumbersome but precise gasometric technique to study enzyme activity. When Kalow demonstrated his spectrophotometer, they were impressed by its speed and simplicity. But they wondered whether it would also work on the rare patients that they had found with low cholinesterase activity. ${ }^{24}$ This had become a problem of growing clinical interest. Donald Gunn, a psychiatrist at the Ontario Hospital in New Toronto, had recently begun using succinylcholine as a paralyzing agent for electroconvulsive therapy. The drug's fleeting action was well suited for the quick procedure. Since Gunn's patients received multiple treatments over weeks or months, it was easy to study their reactions to varied doses of the drug (Figure 1). Gunn had already found two patients who experienced prolonged apnea. One poor man remained paralyzed, while awake, for 45 minutes. Gunn and Kalow began collaborative studies, taking 
118 patients through ECT treatments with doses of succinylcholine ranging from 30 to $1000 \mathrm{mg} .{ }^{25}$ Results showed that the problem was not low enzyme concentration, but low enzyme affinity for its substrates. Since affinity depended on enzyme structure, and enzyme structure depended on amino acid sequence, the difference must have been genetic. When he presented his findings at the Canadian Physiological Society in October 1954, it made front-page news. ${ }^{26}$ Kalow and Gunn expanded their studies to include 443 students, 346 laborers, 1228 people tested for syphilis, and 2442 psychiatric patients. In one extreme case, a psychiatric patient experienced 157 minutes of complete paralysis from a dose that generally produced just five to ten minutes of paralysis; it took a full eight hours for the patient to recover respiratory function. ${ }^{27}$ Kalow pursued large scale testing so that he could be confident in his results before publishing. The delay cost him dearly: he got scooped. In July 1956 a London group published in Lancet a report on a family with low cholinesterase activity. ${ }^{28}$ Kalow felt the sting: "Such little incidents can be damaging to a scientist who thereby loses priority in public view -- even if not in his or her own mind. Lesson to a scientist: always publish as fast as you can." ${ }^{29}$ Kalow drafted a brief account of his own work and published it as a letter in Lancet that September. ${ }^{30}$ He worked quickly and published detailed accounts of many aspects of his work. While the London group had looked only at phenotype, distinguishing normal from atypical activity, Kalow's quantitative analyses using enzyme inhibitors revealed an intermediate 
level of activity. ${ }^{31}$ Studies of seven families in Ontario, Quebec, New York, and Michigan confirmed a Mendelian pattern of inheritance.

It was not just these specific experimental results that fueled Kalow's interest in genetics. The social-scientific contexts of his work made genetics a promising result for an aspiring young scientist. When Kalow arrived in Toronto in 1951, genetics remained on the periphery of medical science. This changed over the next decade, prompted by rapid discoveries in the emerging field of molecular biology. ${ }^{32}$ Recognizing the opportunity, Kalow realized that he needed to learn more about the new science. He apprenticed himself to the local professor of genetics, Norma Ford-Walker. He participated in a 1959 Ciba Foundation Symposium on the Biochemistry of Human Genetics where he joined notables including Luca Cavalli-Sforza, Salvador Luria, Joshua Lederberg, Macfarlane Burnet, and James Neel. ${ }^{33}$

Kalow read widely and learned much that seemed relevant to pharmacology. ${ }^{34}$ Genes controlled antibiotic resistance in bacteria, chemotherapy resistance in tumors, and pesticide resistance in insects. One family of dogs, like his first patients in Berlin, had died from routine doses of procaine. He read about two recently described pharmacologic variants in humans. Some patients developed hemolytic anemia after primaquine prophylaxis for malaria. Others suffered hepatitis or peripheral neuritis after tuberculosis treatment with isoniazid. Kalow also found inspiration in the old insights of Archibald Garrod about human metabolic variation. ${ }^{35}$ Garrod, who studied cases of familial alkaptonuria, 
wrote in 1902 that metabolic variations between humans should be no more surprising than the familiar anatomic variations. ${ }^{36}$ Scientists working for the League of Nations grappled directly with this problem as they worked to standardize measures of the potency of hormones and realized that drug response varied from person to person. ${ }^{37}$ The existence of genetic influences on drug response seemed obvious, appropriate, and relevant.

Kalow compiled his research and literature review into his 1962

Pharmacogenetics. His readers could find everything from a primer about the genetics of bacteria, insects, and mammals, to discussions of abnormal drug reactions caused by metabolic variations, his own work on serum cholinesterase, and why asparagus altered the aroma of urine in some people but not others. Although he knew that these were obscure topics, he saw much promise in the field: "One may ask whether the field of investigation here called pharmacogenetics is the end of a road or the beginning of a new one. There are many signs which suggest that the number of established instances of a hereditary control of pharmacologic responsiveness will considerably increase in the near future. ${ }^{\prime \prime 38}$

Thoroughness again cost him priority. As he worked on this long project, American geneticist Arno Motulsky published a 1957 article in the Journal of the American Medical Association that described the intersection of pharmacology and genetics, suggesting that adverse drug reactions could arise from "otherwise innocuous genetic traits or enzyme deficiencies." ${ }^{39}$ German pharmacologist 
Friedrich Vogel coined the term "pharmacogenetics" in 1959. Despite this, Kalow's book still generated considerable interest. ${ }^{41}$ When he presented his work at the New York Academy of Sciences in October 1962, it was picked up by the New York Times. As described in an editorial, "differences in genetic make-up between individuals make for radically different degrees of risk in taking drugs." ${ }^{\prime 42}$ With the thalidomide scandals in 1961 and the Kefauver hearings from 1959 to 1962, there was great interest in anything that might improve drug safety.

\section{The Technology of a Genetic Argument}

It is worth looking closely at how Kalow made his case that individual variation in drug response was under genetic control, and how his strategies related to broader developments in the history of genetics and molecular biology. Kalow developed three arguments in parallel, based on the technology of biochemical enzymology, on an analogy to animal models, and on an appeal to the intuitive logic of natural selection.

The first argument depended on his laboratory practice. Kalow collected a blood sample and spun it down to isolate the serum. He diluted the serum and added a substrate, benzoylcholine. Using a spectrophotometer, he shined a light across the sample and recorded the absorption spectrum in order to measure substrate concentration. The rate of change of concentration over time measured enzyme activity. This was one of many ways that pharmacologists employed spectrophotometers in their research in the $1950 \mathrm{~s}^{43}$ Kalow, however, developed a 
special trick. He took a second sample and added both the substrate and an inhibitor -- dibucaine. By repeating the measurements, he could measure inhibited enzyme activity. He called the degree of inhibition caused by dibucaine, expressed as a percentage, the "Dibucaine Number" (DN). Calculated in this manner, the DN did not depend on the concentration of the enzyme in the serum. Instead, it depended on something more fundamental, the affinity of the enzyme's binding sites for different substrates. Binding affinity, in turn, depended on the physical structure of the enzyme. Since enzyme structure depended on its amino acid sequence, the structure and the resulting affinity and enzyme function had to be under genetic control. The DN was, as Kalow concluded, "genetically determined." ${ }^{44}$

Kalow's experimental method made an occult process legible and reduced it to a single number for each patient and to a graph of DN distribution in the population of patients studied. ${ }^{45}$ This facilitated comparisons between individuals and between groups and enabled the construction of arguments about difference. Kalow's methods produced a very different argument for genetic causation than the traditional method of tracing a trait through a family tree. Genetic research, from Mendel's peas to Davenport's eugenic family histories or Morgan's fruit flies, had relied on intuitive notions of heritability ${ }^{46}$ If a trait bred true from one generation to the next, it must be heritable which meant, by the mid-twentieth century, that it was carried by a gene. ${ }^{47}$ Such studies of human genetics depended on careful reconstruction of family lineages. Kalow's method, in contrast, allowed arguments 
to be made about genetics based only on only on the study of living, unrelated individuals. ${ }^{48}$

The technique, however, did allow Kalow to make more familiar kinds of genetic arguments. For instance, when Kalow plotted the DN of research subjects and their families, he found a trimodal distribution (Figure 2). Most people had a DN between 70 and 90 . Others ranged between 40 and 70. A very few individuals had $\mathrm{DN}^{\prime}$ s of less than twenty. ${ }^{49}$ Kalow read this distribution as evidence of two basic levels of activity, high and low, caused by two different enzyme forms, active or not, generated in turn by two different genetic alleles. He interpreted intermediate activity as evidence of heterozygosity: individuals with one active and one inactive allele. DN, the product of a complex analysis of spectrophotometry and enzyme biochemistry, appeared to be a conventional Mendelian trait. This kind of argument about intermediate forms as evidence of Mendelian inheritance had been recently and famously made by both Linus Pauling and James Neel for the inheritance of sickle cell anemia. ${ }^{50}$

The parallels between Kalow's work and that of Neel and Pauling raises important questions the place of pharmacogenetics in the development of molecular biology. Historians of molecular biology have focused on several stories: how researchers studied the relations of nucleic acids and proteins to the flow of genetic information, and how they deciphered the structure of proteins and nucleic acids in order to understand their function. ${ }^{51}$ This research depended significantly on the import of new laboratory technologies from the physical 
sciences into the life sciences, especially electron microscopes, x-ray crystallography, ultra-centrifuges, radioisotope probes, and spectrophotometry. ${ }^{52}$ But there were other important topics for which researchers attempted to unlock the molecular secrets of life. The Rockefeller Foundation, for instance, funded research on photosynthesis and bioenergetics, as well as on enzyme biochemistry more broadly. Much of this work relied on spectrophotometry. ${ }^{53}$ The researchers themselves saw the field broadly. G. Montalenti, in the opening remarks of the Ciba Foundation's 1959 symposium described valuable work on both structural analysis of genes and chemical analysis of gene expression. ${ }^{54}$ The latter is where Kalow's work fit in.

Kalow was not interested in the specific structure of cholinesterases or in the genes responsible for them. Instead, he focused simply on describing their function and variations. While this might seem peripheral compared to the work on the double helix that has received so much attention, molecular biologists in the 1950s were quite interested in his work. Kalow, for instance, presented his work on cholinesterase variants at the 1959 symposium. Other speakers emphasized the importance of work on drug metabolism. L.S. Penrose, who directed the Galton Laboratory at the University of London, described the value -- to geneticists -- of the identification of drug metabolizing variants: "Any gene may be abnormal in a particular environment. In this connexion, it is noteworthy that entirely unsuspected genetical sensitivities to artificial new environments produced by synthetic drugs have been brought to light." ${ }^{55}$ Luca Cavalli-Sforza similarly 
described the interest of "genetical analysis" of drug response variants. ${ }^{56}$ Kalow had a particular approach to genetics, one grounded in the concerns and techniques of medical pharmacology. His methods, however, allowed him to make powerful arguments about the genetic determinants of drug metabolism and engage the burgeoning community of molecular biology.

\section{Animal Pharmacology and the Argument by Analogy}

Even as Kalow explored the details of enzyme function and its genetic determinants, he also looked to the level of organisms and species in order to make claims about the relevance of genetics. When Kalow began his work in pharmacology in 1947, he quickly learned that different species responded differently to drugs and poisons. His initial study of the poison phenylethanolamine found markedly different effects in different animal species. ${ }^{57}$ When he moved on to procaine, he learned that it too had species-specific effects. Long used as a local anesthetic in humans, procaine had recently generated attention as a doping agent in horse racing: in horses, it acted as a central nervous system stimulant. ${ }^{58}$ His work revealed a possible basis for this effect: human and equine procaine esterases had different affinities for different substrates. Humans, for instance, metabolized procaine 16-times faster than horses did. ${ }^{59}$ This interest in species differences followed Kalow to North America. When he studied cardiac physiology in Philadelphia, his results differed from those reported by another team. He suspected that inter-species variation explained the discrepancy: "We 
have no explanation for the divergence of our findings (vasodilatation) from those of MacDowall (vasoconstriction) other than a species difference since his experiments were made on cats and ours on dogs." ${ }^{60}$ When he moved to Toronto and began studies on curare, he found that its potency varied significantly between frogs and mammals. ${ }^{61}$ During his initial years there, he had to earn extra money by testing horses at a local racetrack for morphine. Like procaine, it had stimulant effects in horses and had been banned as a doping agent. ${ }^{62}$

Intrigued by these results, he surveyed the literature in search of other examples of differences in drug response between animals. He found many. The story began with rabbits. In 1852 a Viennese scientist noted that a population of rabbits survived on a diet of belladonna leaves. This was notable because belladonna, also known as deadly nightshade, contained atropine, an alkaloid that would be lethal to most mammals. Follow up studies in 1910 found that certain rabbits, but not all of them, possessed an atropine esterase that rendered belladonna harmless. Most scientists dismissed these findings. Kalow later speculated that "the time was not ripe for an acceptance of the idea that there are pharmacogenetic differences between various stocks of rabbits. ${ }^{\prime 63}$ Subsequent study, however, confirmed the existence of the atropine esterase that allowed rabbits to thrive in fields of belladonna that would have left other animals wideeyed or dead. A 1943 study, for instance, found that roughly half of 181 rabbits tested possessed the enzyme. The prevalence varied between rabbit populations. While "a New Zealand White race" lacked the esterase completely, other strains 
had it in many individuals, and still others, including "a pure chincilla race," produced both enzyme-possessing and non-enzyme-possessing bunnies. This pattern "suggests the existence of racial differences," at least among rabbits. ${ }^{64}$

Kalow found many other relevant examples. Horses, humans, rabbits, and monkeys all had different levels of esterase activity; goats and cows had none. ${ }^{65}$ Dogs were poor acetlyators. Sheep lacked glucose-6-dehydrogenase. Morphine response differed radically: "Some people always react to morphine like cats--with excitement; most people react like dogs and become sedated." ${ }^{\prime 66}$ Species differences were most obvious with insecticides. The goal was to find chemicals that killed insects with minimal toxicity to humans and other mammals. Evidence of inter-species differences in drug metabolism posed a challenge for scientists who wanted to extrapolate from animal research to human use. As Kalow warned, "the fate of the drug may vary substantially from species to species, and conclusions reached by studying the fate of the drug in other species are not directly applicable to man." ${ }^{67}$

Kalow also found evidence of variation at a finer level, between strains of the same species. Only certain rabbit races had atropine esterase. Harvard rats could tolerate a 44-mg dose of thiourea, but Hopkins rats could only tolerate $4 \mathrm{mg}$. This was not a function of Harvard stalwartness: some wild-type Norway rats could survive $1340 \mathrm{mg}{ }^{68}$ When a laboratory catastrophe in Bar Harbor exposed countless mice to chloroform, mortality rates ranged between zero and $74 \%$ across different strains. Susceptibility to alcoholism varied as well. While many rats 
strains avoided alcohol, "one strain easily became drunkards when given a vitamin-deficient diet." ${ }^{19}$ As Kalow later wrote, "The more precisely one measures the effects of a drug in laboratory animals, the more likely one is to find differences between strains." ${ }^{\prime 70}$ To the extent that differences between (and within) animal species reflected genetic differences, then such species-specific differences in drug metabolism, especially among laboratory animals raised in controlled environmental conditions, must have reflected genetic differences.

Kalow was not alone in his interest in the precedent offer by species and subspecies variation in drug response. When Motulsky published his initial discussion of genetics and drug reactions in 1957, he admitted that no one had yet made a convincing case that genetic differences in drug metabolism existed in humans. However, he too knew about the story of rabbits and atropine esterase, and about strains of mice that were resistant to insulin. He described how "Qualitative differences between species also exist," with morphine, for instance, causing hyperexcitability in horses and cats, but not in humans. ${ }^{71}$ Brodie had similar interests. In his introduction to the First International Pharmacological Meeting, held in Stockholm in 1961, Brodie noted that "Much work on the problem of species and strain differences remains to be done ... Is it possible that enzymes which appear to be the same in two species are actually different?" Like Kalow, he had been struck in his own work by marked differences in drug toxicity between species: "I well remember our surprise when Dr. Axelrod and I found that phenacetin, an unusually non-toxic drug in man, was quite toxic in dog due to the 
accumulation of the methemoglobin-forming free amine in this species." ${ }^{172}$

Although all were aware of species-level variation, it was Kalow who took the step of compiling an exhaustive review of existing knowledge of the differences in drug metabolism between species of bacteria, insects, and mammals, as well as between subspecies and strains of mammals. To the extent that metabolism, like anatomy, was under genetic control, the pervasiveness of metabolic variation demonstrated the relevance of pharmacogenetics.

\section{Natural Selection and an Argument Based on Intuition}

The ubiquity of drug metabolizing variants across the animal kingdom raised an obvious question: why was that the case? As Kalow recognized the prevalence of atypical esterases in 1954 and thereafter, he began to wonder about the meaning of the finding. Cholinesterase initially had no known function other than its impact on drug metabolism. Since it seemed impossible that drug metabolizing enzymes had evolved eons ago simply to be on hand once doctors developed pharmaceuticals, Kalow pondered what their physiological role had been in a world before procaine and succinylcholine. When his initial research suggested a higher incidence of atypical activity in psychiatric patients, Kalow suggested that cholinesterase played a role in neurophysiology and the pathophysiology of mental illness. ${ }^{73}$ Subsequent research, however, did not bear this out. ${ }^{74}$ His next hypothesis was more prosaic. Perhaps cholinesterase variants mediated response 
to potential environmental toxins, specifically some found in potatoes and asparagus. ${ }^{75}$

Kalow's argument here paralleled one that was being made with increasing frequency in the 1950s and 1960s: that genetic variations existed because of evolutionary selective pressures on human and other animas. A.C. Allison had famously made the case in 1954 that sickle cell trait persisted in tropical populations because it provided selective advantage in settings of endemic malaria. ${ }^{76}$ Kalow's examples, though less dramatic, followed the same logic. The enzymes that metabolized drugs must have evolved to manage various environmental toxins, especially those from food. Since different animals evolved in different environments, they evolved different toxin metabolizing repertoires. When animals lived in the same environment, especially in controlled laboratory conditions, these differences became latent, only to be unmasked when exposed to drugs and other chemicals.

Some researchers were cautious when making these arguments. Montalenti had been puzzled by the way in which medical treatments had revealed unsuspected human variations: "it is noteworthy that entirely unsuspected genetical sensitivities to artificial new environments produced by synthetic drugs have been brought to light." ${ }^{\prime 77}$ While he was not exactly sure what had maintained those alleles in the population, he suspected that the answer lay in natural selection: "it is reasonable to assume that any gene found persistently in human populations is likely to be in a fairly stable state with respect to selective forces. ${ }^{\prime 78}$ Motulsky, 
citing the example of sickle cell and malaria, also suspected that "some selective advantage" maintained drug metabolizing variants in populations. ${ }^{79}$

Others were more assertive. Brodie, whose work identified the liver enzymes responsible for drug metabolism, was more confident in his speculation: "One cannot help asking whether the latent capacity of these enzymes developed in the course of evolution to enable the organism to respond to the sustained presence of large amounts of foreign organic compounds ingested in food." 80 Drugs were simply examples "of a class of compounds to which the organism has been exposed over the ages." ${ }^{81}$ Differential exposure over evolution had led to differential genetic capacity. Kalow's thought closely paralleled Brodie's. As Kalow later wrote: "Since drugs are part of the human environment, it is natural to encounter hereditary factors that affect the responsiveness of the human organism to drugs, and one should find these factors in all forms of life which are appropriately studied." 82

Kalow's interest in the evolutionary argument persisted throughout his career. For instance, in June 1997 evolutionary theorist Stephen Jay Gould published an extensive critique "ultra-Darwinian fundamentalists" who believed that natural selection was responsible for every complex trait. ${ }^{83}$ Gould argued for a more pluralistic vision, in which natural selection was the most important of several mechanisms that generated new traits. This triggered an angry exchange with psychologist Steven Pinker about the merits of evolutionary psychology. ${ }^{84}$ Kalow and a colleague entered the fray, offering pharmacogenetics as an example 
of the non-adaptationist mechanisms that Gould favored. A pharmacogenetic trait could emerge and persist, not because it conferred current selective advantage to an individual, but because it provided potential advantage to the species should the environment change: "they constitute a sort of biological insurance policy for the species, rather than for the individual. Like Professor Gould's 'spandrels,' they have no particular use when they arise, but may acquire a use later on." 85 Gould replied by tweaking their interpretation and suggesting that natural selection might favor "more variable species" (i.e., ones with more variable drug metabolism enzymes), a distinct mechanism from the usual focus on natural selection of individuals. $^{86}$

\section{The Racialization of Pharmacogenetics}

The analogy to species differences and the appeal to evolutionary logic both served to naturalize and justify genetic difference. They also naturalized racial difference: to the extent that different races had experienced different foods and environmental toxins, they too should have developed differently tuned drug metabolizing enzymes. This turn to race, at the very origins of pharmacogenetics, can be seen clearly in Kalow's work.

Kalow's interest in species and subspecies differences extended to studies of humans. As he surveyed the literature in the late 1950s, he found many reports about human racial differences in drug response. ${ }^{87}$ H.A. Paskind, working in Chicago in the 1920s, showed that whites and blacks had different hemodynamic 
responses to atropine ${ }^{88}$ K.K. Chen and Edgar Poth, working at Hopkins, found that whites, blacks, and Asians had different mydriatic responses to cocaine, euphthalmine, and ephedrine. ${ }^{89}$ Meanwhile, British and German researchers, working in Africa and Asia in the 1920s, observed that some Asians and Africans experienced hemolytic anemia after primaquine treatment for malaria; Europeans did not. ${ }^{90}$ During World War II, US Army physicians recognized a similar risk of hemolytic anemia among African American soldiers. In 1954 researchers traced this risk to low activity of a specific red blood cell enzyme, glucose-6dehydrogenase. ${ }^{91}$ Continuing work found high rates among Negroes, Orientals, Sardinians, and Greeks, but low rates in Europeans, Ashkenazi, and Peruvian Indians. ${ }^{92}$ The side effects of isoniazid also had a racial distribution. As tuberculosis treatment campaigns took isoniazid worldwide, clinicians observed two sorts of side effects, depending on patient's acetylation capacity. Slow acetylation carried a risk of peripheral neuritis, while fast acetylation led to hepatitis. Chinese, Japanese, and Eskimos were likely to be fast acetylators, Sudanese slow, and Caucasians and African-Americans mixed. ${ }^{93}$ Kalow heard rumors that operative mortality varied between populations, with dark skinned patients in the United States, Jamaica, or Fiji at highest risk. ${ }^{94}$ Racial differences in the ability to taste specific substances also existed, with high rates of non-tasters of phenylthiourea among Europeans and Asians, but low rates in Africans and American Indians. ${ }^{95}$ 
Motulsky was similarly aware of how drug metabolizing traits varied across ethnic groups. He began his 1957 discussion with the unusual prevalence of primaquine-induced hemolytic anemia in African Americans. He suspected that many of these ethnic differences reflected underlying genetic differences: "any drug reaction that is more frequently observed in a given racial group, when other environmental variables are equal, will usually have a genetic basis." ${ }^{\prime 6}$ Even after the 1950 UNESCO statement on "The Race Question," that condemned the many myths and misuses of race, race remained an appealing analytic category for medical researchers. ${ }^{97}$

Although Kalow knew about these varied examples, he had limited personal experience with racial variation. While stranded in the Japanese Empire during the war, he had encountered the "exotic" orient. His travel throughout Japan, China, Vietnam, and Korea, was "a truly broadening experience": "To us as newcomers, the first overwhelming impression was the strangeness of the country: the exotic faces, the traditional dress, the houses, the streets. It was all so different from home. ${ }^{\prime 98}$ Toronto in the mid-1950s offered a more limited sample of research subjects. He tested people from Canada, Great Britain, Poland, Ukraine, Yugoslavia, Russia, France, Italy, Austria, Germany, Hungary, and "31 other countries (mostly European)." ${ }^{\prime 99}$ When he found no differences between groups, he blamed the homogeneity of his research population: "The great majority of all investigated persons were of European extraction. There was no evidence for a different incidence of atypical esterase among Europeans, or between Europeans 
and North Americans, or between religious groups." ${ }^{100}$ Even these limited studies, however, did occasionally yield a tantalizing lead: "We had an opportunity to observe atypical esterase in one Arabian family and one Persian." ${ }^{101}$ Kalow's concern that the limited geographic diversity of his research subjects would limit their pharmacogenetic diversity reflects what was then a significant assumption about the distribution of human genetic diversity.

In his writings about these sorts of group differences, Kalow did not distinguish between species, subspecies, and races as categories of different ontological status. This was a question that scientists had debated since the eighteenth century. Beginning in the 1960s, biologists increasingly tried to enforce a distinction: species are a fundamental unit of biology, while subspecies and races are arbitrarily defined. ${ }^{102}$ In this strict definition, the existence of species-level differences ought not provide a compelling analogy for the existence of subspecieslevel differences. Kalow, however, lumped the categories together, for instance offering explanations for "the different responses of breeds, strains, races, species." ${ }^{103}$ Subspecies variations, such as those between white and chincilla rabbits or between Harvard and Hopkins rats provided a more credible precedent. However, it remained unclear to what extent differences between inbred laboratory strains might parallel the natural variations between human populations.

Another point becomes relevant here. Scholars have described how model organisms -- fruit flies, mice, viruses, and others -- standardized biological research and facilitated the development of modern genetics. ${ }^{104}$ Kalow's work demonstrates 
something different: the importance of lack of standardization. He and the researchers whom he read did not rely on one or a few animal models. Instead, they worked with a menagerie of different ones -- mice, rats, cats, dogs, horses, and various strains of each. This diversity became relevant for Kalow's analyses. Seeing heritable pharmacogenetic differences across so many different subspecies and species, Kalow expected that comparable racial and ethnic differences existed in humans.

Researchers' interest in race and pharmacology had real consequences. At the First International Pharmacological Meeting in 1961, where Kalow played an active role, Brodie posed the basic challenge: "An ever-recurring question is which species is closest to man in metabolizing drugs? One might indeed ask 'What man?', since individuals of homo sapiens metabolize a given drug at vastly different rates. In fact this biochemical variability is a major difficulty in evaluating drugs in man." ${ }^{105}$ Kalow worried about this same problem: "gene frequencies vary between populations. This means that a drug that has been shown to be safe in one population is not necessarily that safe in another racial group." ${ }^{106}$ Pharmacologists could not extrapolate between human populations, let alone between mammalian species, in their studies of drug safety and efficacy. When the New York Times covered Kalow's 1962 presentation at the New York Academy of Sciences, both the article and the accompanying editorial highlighted the problem of the differential susceptibility of human populations to adverse consequences of drugs. ${ }^{107}$ 


\section{Expanding the Evidence Base}

Kalow's research, literature reviews, and rhetorical strategies all contributed to the consolidation of pharmacogenetics in the late 1950s and early 1960s. His work, however, did not stop there. Instead, over the next forty-five years he continued to make the case for pharmacogenetics. As he did this, he remained engaged with two central problems: the politics of race in science, and the challenge of assessing the relative importance of genetics and other factors.

Kalow's advocacy of the relevance of genetics to pharmacology and medical therapeutics faced some daunting challenges. When Kalow published Pharmacogenetics in 1962, scientists knew of six human drugs metabolizing enzymes with significant polymorphisms. Most of these did not influence drugs used widely in North America. Over the next seventeen years researchers identified only two additional variants. ${ }^{108}$ Given these constraints, Kalow worked on three fronts to make the case for the relevance of genetics to pharmacology and therapeutics.

First, he remained on the lookout for any evidence of significant pharmacogenetic variants. Collaborating with anesthesiologist Beverly Britt he helped characterized one of the most terrifying ones: malignant hyperthermia. In the 1960s anesthesiologists described a new syndrome in which patients developed fatal hyperthermia (with fevers over $110^{\circ}$ ) and muscle rigidity during routine anesthesia with halothane and succinylcholine. Clinical studies quickly revealed 
that susceptibility ran in families, suggesting a genetic basis. ${ }^{109}$ Because this was a catastrophic reaction to a widely used drug, Kalow called on all physicians to search family histories for anesthetic complications before taking patients to surgery. Racial and species variations again seemed relevant. Studies in fourteen families at the Hospital for Sick Children in Toronto found a frequency of 1:14,000, "All three major racial groups -- Oriental, Negro, and Caucasian -- were involved."110 Research in rabbits, rats, dogs, chickens, and pigs revealed a similar syndrome in pigs, but with a different underlying pathophysiology. ${ }^{111}$

Second, Kalow continued to publish review articles that emphasized the relevance of pharmacogenetics. ${ }^{112}$ Improvements in screening technologies facilitated this work. During the 1960s, researchers led by Harry Harris at the Galton Laboratory in London learned how to use electrophoresis to screen for enzyme variants. They found person-to-person differences in one-third to one-half of all enzymes. Kalow recognized the implications of this: "If his figures are representative, well over half of the human enzymes could be genetically variable. This should have an impact on concepts of human variation in response to drugs." ${ }^{113}$ Parallel work by Elliott Vesell at the National Institutes of Health used twin studies to reveal the impact of genetic variation of the metabolism of widely used drugs, with heritability ranging between $87 \%$ and $99 \% .{ }^{114}$

Third, Kalow continued his own research on esterases. Spectrophotometers gave way to inhibitor-impregnated filter paper that allowed Kalow's team to screen 200 samples overnight. The new technology enabled broader population studies. 
An initial study of 6500 Brazilians found intermediate cholinesterase activity in $2.8 \%$ of the sample. ${ }^{115}$ Kalow could compare this to findings by other researchers from other populations. He found low rates of atypical forms in Australian Aborigines (1\%) and Brazilians (2.8\%), and higher rates in Canadians (3.8\%), Berbers (4.0\%), Jews (6.3\%), and Czechoslovakians (8.5\%) (Figure 3). His initial interpretation emphasized homogeneity: the Brazilian result added "one more piece of evidence confirming the remarkable similarity of the frequencies of the E1 u and E1a alleles among populations in the world."116 However, as research accumulated in the 1970s, populations seemingly diverged, with atypical cholinesterase found in 1:3000 Caucasians, 1:100,000 Negroes, and 1:400,000 Orientals. ${ }^{117}$

The accumulating evidence of pharmacogenetic variants garnered attention from health authorities. In 1964 the World Health Organization had established a study group on drug efficacy and safety. This group was interested from the outset in the racial variations in responses to primaquine and isoniazid. ${ }^{118}$ In 1970 the WHO Advisory Committee for Medical Research convened a scientific group on the role of genetic factors and appointed Kalow as chair. He argued that the existence of racial variations in drug metabolism created a potential public health problem: "Since most drugs are at present initially tested on limited populations, interethnic variability could be of practical importance as well as academic interest when the drugs are later used on a world-wide scale." ${ }^{119}$ With its existing drug monitoring program, which had documented 80,000 adverse reactions in fifteen 
countries over four years, Kalow felt that the WHO was well positioned to conduct population-based studies for "elucidating ethnic variability in the metabolism of, and in responses to, drugs." ${ }^{120}$

\section{Rhetoric and Politics of Genetics and Race}

As racial variations attracted increased attention, social and political tensions became evident in Kalow's work. He knew from some initial work on pharmacogenetics and psychopharmacology that certain kinds of genetic arguments could be controversial. As he wrote in 1975, "Any suggestion that the mind can be subject to the same variations as are height, eye colour, etc., will be understood by some people and yet provoke a great outcry in the general populace." Mention of a genetic basis for behavior "creates many emotional problems." The situation was especially acute for genetics and race: "the whole genetic area has been politicized by the concept of race. While most geneticists would see 'races' merely as statistical entities representing higher than usual concentrations or of high proportion of certain configurations of genetic information, (Montagu, 1969) the general public does not share this view." ${ }^{121}$ It is remarkable that Kalow continued to make the case for race in pharmacogenetics despite his awareness of Ashley Montagu's critique of race.

These tensions appear in the careful rhetoric and inconsistencies seen in Kalow's accounts of race in the 1970s into the 1980s. During this time, Kalow shifted his focus from measuring the prevalence of atypical forms to deciphering 
specific biochemical pathways. For instance, by studying the concentration of different metabolites in the urine of his research subjects, his team identified two distinct metabolic pathways for the barbiturate amobarbital and then, using twin studies, demonstrated a genetic basis. ${ }^{122}$ In one typical study, Kalow recruited 144 first-year medical students to ingest a fixed dose of amobarbital; 129 of them submitted urine samples at 36 hours. ${ }^{123}$ The researchers studied metabolite levels to determine relative activity of two specific metabolic pathways, C-hydroxylation and N-glucosidation. Most students exhibited twice as much hydroxylation as glucosidation (Figure 4). Fourteen, however, had the opposite pattern. These atypical students caught Kalow's eye: "When preparing for the repeat investigations of students whose data seemed to be of particular interest, we were alerted by noting immediately and in succession some Chinese names among those with high $\mathrm{N}$-glu excretion.." ${ }^{124}$ Four of the fourteen students with atypical activity were Chinese, as compared to only six among the 115 others, a difference that was statistically significant.

Kalow interpreted this finding with an odd caution. Even though he knew that "substantial racial or ethnic differences have been observed for the frequencies of all genes," he professed uncertainty about whether the racial variation in amobarbital metabolism was "unique or whether it represents a more or less common phenomenon."125 Follow up studies confirmed the pattern. While 10 of 20 oriental students had this unusual pattern, only 1 of 20 Caucasian students did. Kalow strengthened his conclusion: "Thus, there is no doubt about a racial 
difference in the mix of amobarbital metabolites." ${ }^{126}$ As they continued to explore this question, Kalow's team used a specific graphing technique, a probit plot (Figure 5), to transform overlapping Gaussian distributions (i.e., two overlapping bell curves) into distinct parallel lines. ${ }^{127}$ This technique provided a starker visual argument for difference between groups. But once again he remained cautious: "The racial differences in the appearance of amobarbital metabolites represent an observation at the descriptive level without any definite assignment of causes. While data collected among Caucasian twins and families suggested strongly that amobarbital elimination is under genetic control, such an observation made within one race does not prove a difference between races to be genetic. It therefore, should be emphasized that we cannot distinguish with certainty between environmental and genetic causes for the observations reported here. It nevertheless would be improper to dismiss the possibility of genetic interpretations. ${ }^{\prime 28}$

While working on amobarbital, Kalow also used other drugs as metabolic probes. One, the antihypertensive debrisoquine, had been used by other researchers to reveal differences in a specific hydroxylation pathway between Britons and Kenyans. ${ }^{129}$ He performed his own study of debrisoquine metabolism. He studied 51 students, of whom 13 were "Oriental (Chinese) origin" and found that the pattern of metabolites was "influenced by the ethnic origin of the subjects." 130 This finding made sense: "ethnic differences definable by gene frequency occur in the cytochrome P-450 system as they do in all other, genetically 
controlled, drug-metabolizing enzyme systems." ${ }^{131}$ Yet despite his growing confidence reporting in racial differences, Kalow remained defensive: "The data described here were not originally collected for the purpose of studying ethnic differences." ${ }^{132}$ The ethnic difference "was discovered incidentally." Though wary about his small sample size, he reported the result because "the difference was statistically significant." ${ }^{133}$

A third study, however, broke this pattern of racial findings. Other researchers had found differences in antipyrine metabolism between white Britons living in London and Indians living in India. Kalow recruited a sample of 48 Caucasian and 19 Oriental students and measured antipyrine urine metabolites at 48 hours. This time he found no differences between the groups: "The fundamental similarity in antipyrine metabolism in the two populations is remarkable, because metabolite patterns of antipyrine differed significantly between subjects, and because the same two populations are known to differ much in their capacity for other drug oxidations."134 A parallel study, looking at antipyrine metabolism in rats, provided another surprise: "It must be noted that the metabolite profiles are remarkably similar in man and rat.".135

Kalow's writings in the late 1970s and early 1980s present a puzzle. He described surprise when he found racial variations in amobarbital metabolism, and surprise when he did not find them for antipyrine (and even more surprise with the lack of human-rat differences). When he reported his debrisoquine findings, he essentially apologized for doing so. These narratives of surprise and apology 
suggest that Kalow experienced discomfort about his pursuit of a palpably politicized science. ${ }^{136}$ As he had first done in the 1950s and 1960s, he emphasized specific narratives that served to naturalize the findings of difference.

First, he worked with other researchers as they mapped ethnic and racial difference in drug metabolism on a global scale. They continued to find measurable differences whether they looked at the various cytochrome P-450 systems or at cholinesterase, paraoxonase, or acetylation. ${ }^{137}$ Second, he fit these data into the old evolutionary stories: "It should not surprise us to discover that the optimal structure of our biochemical defence systems is somewhat different in people of different regions of the world. There are regional characteristics of flora and fauna, and hence there must be regional differences in naturally occurring toxic components of food or other environmental products." ${ }^{138}$ Third, he preserved the slippage in his work between species and races. Commenting on the unusual extent of variation within human populations, Kalow noted that "Only a cosmopolitan species of brown bat seems to be genetically as diverse as are people within a given race." ${ }^{139}$

Kalow officially retired in 1982 but remained active in the field. In 1985 he organized a major conference on racial and ethnic variations in drug metabolism that produced an influential collection of papers on the subject. ${ }^{140}$ When the New England Journal of Medicine published a report on racial differences in propranolol metabolism, it recruited Kalow to write the accompanying editorial. He took the opportunity to reiterate his old argument: "For the physician, the lesson of the Zhou 
study should be the importance of increased awareness of the possibility of differences in drug response and in dose requirements among patients from various ethnic and racial groups. ${ }^{\prime 141}$ He encouraged the World Health Organization and pharmaceutical companies to rise to this challenge: "The best scientific course for further action is to encourage systematic research to determine the factors, enzymes, and responses that tend to differ among the major races, and those that tend to be alike." As Kalow's work slowed, others took the lead and published ever more studies of racial differences in drug metabolism, ${ }^{142}$ and then reviews based on these new findings. ${ }^{143}$ Researchers continued to slip easily between studies on specific populations, such as Swedes and Han Chinese, to conclusions about races, whether Caucasian or Oriental. ${ }^{144}$

Controversies about race even reached Kalow late in his career. By 2002 he had ceded lectures in the pharmacology course at the University of Toronto to his junior colleagues. Each year the course included a routine lecture on pharmacogenetics that covered ethnic differences in drug effects between Africans, Asians, and Europeans. In 2002, however, the students were outraged. As Kalow wrote, "The professor was shocked to experience ugly protests by some students who called him 'racist."'145 Kalow submitted an editorial to the local student newspaper, the Varsity, defending his colleague and the discussion of race: race was not a political issue, but simply a scientific one. He also tried to make the case more widely. Responding to a 2001 New England Journal of Medicine about the contested nature of race, he made his own case for why physicians ought to 
consider their patients' racial and ethnic backgrounds. The New England Journal rejected it without review. ${ }^{146}$ He did succeed, however, in publishing a shortened defense of race in a specialty journal. ${ }^{147}$

\section{Genetics and Other Possibilities}

Even though genetics in general, and race in particular, have received increasing attention as popular explanations for inter-individual variation in drug response, they have existed in parallel with other explanations. Recall that when Kalow was first assigned to the two cases of lethal reactions to procaine, his mentor, Hans Herken, had suggested that the problem was malnutrition. As Kalow pursued genetics, other researchers focused on nutrition and other environmental influences. In the early 1950s work on chemical carcinogenesis showed that specific drugs could influence the metabolism of other drugs, up- or downregulating drug metabolizing enzymes. ${ }^{148}$ When the writings of Rachel Carson focused attention on environmental toxins, pharmacologists demonstrated how insecticides, including DDT, could induce the metabolism of drugs in humans. By the early 1970s many inducers of drug metabolism had been found, including insecticides, herbicides, oils, aromatic hydrocarbons, dyes, nicotine, preservatives, plant alkaloids, xanthines, flavones, ozone, and carbon monoxide. ${ }^{149}$

It was this work, grounded in biochemical pharmacology, that identified liver microsomal enzymes, especially the cytochrome P450 system, as an important site for drug metabolism. ${ }^{150}$ A New York group even demonstrated that 
food, whether charcoaled steaks, cabbage, Brussels sprouts, or the Atkins diet could accelerate the metabolism of widely used drugs. ${ }^{151}$ These studies found high rates of intra-individual variability: as research subjects changed their diet, smoking habits, or other environmental exposures over weeks or months, their drug metabolism shifted as well. ${ }^{152}$ Drug metabolizing capacity was not a fixed characteristics of individuals. Instead, it responded to individuals' chemical environments. Other studies found that apparent racial and ethnic differences, for instance between Londoners and Gambian or Sudanese villagers, also disappeared when diet and other environmental exposures were taken into consideration. ${ }^{153}$ Kalow interacted with this environmental tradition throughout his career. In the 1960s he participated in conferences with Brodie, Alan Conney, and many of the others who led the research on environmental factors that shaped drug metabolism. As he wrote at the start of his 1962 Pharmacogenetics, "If this book stresses the existence of hereditary influences on pharmacologic response, this should not be taken as an attempt to minimize the importance of the effects of internal and external environment. One may consider the total variation in the response to drugs as being caused by both hereditary and nonhereditary forces." ${ }^{154}$ Later, during his work on amobarbital metabolism, he worried that the diverse food exposures of the increasingly diverse Toronto population might confound his findings: "If one looks at the Restaurant Guide in the yellow pages of the Toronto Telephone Directory, one finds captions indicating type of cuisine, stating alphabetically with American, Arabian, Armenian, Austrian, Chinese, Croatian, 
Cuban, Czechoslovakian, Danish, and so on, finishing with Vietnamese ... It seems justified to assume that different people are routinely exposed to different enzyme inducers or toxic substances contained in their food and drinks. Thus, we explicitly recognize that different people are exposed to different environments, and that life in the same city does not indicate exposure to the same environment."155 It made perfect sense to Kalow that the genetic and environmental traditions of drug metabolism research would co-exist. They were, after all, linked by the familiar evolutionary narrative. As animals evolved, they developed metabolic systems that could protect them from environmental chemicals and toxins. Natural selection favored metabolic diversity that allowed organisms to adapt to changing environmental conditions. ${ }^{156}$ Kalow knew that the genetic and adaptive components could be difficult to sort out: "Many studies with probe drugs comparing different populations have given results that are equivocal in terms of the nature-nurture interplay. ${ }^{\prime 157}$ He did not see this as a problem. Instead, it was simply an appropriately complex reflection of a complex system: "All these observations provide a cautionary note against simplistic genetic or non-genetic interpretations of ethnic differences in metabolism data." ${ }^{\prime 158}$

From the 1950s into the 1990s, the research on the genetic and environmental determinants of drug response developed in parallel, often in synergy. A third discourse also emerged, one that that emphasized the importance of non-compliance. ${ }^{159}$ With estimates that a typical American patient takes only half of prescribed medications, non-compliance has a huge impact on serum drug 
levels. This likely dwarfs most genetic and environmental factors and may be the most significant determinant of drug response and therapeutic effectiveness. By the early 1990s, individual variability in treatment response was over-determined, with more explanations available than were usually needed to explain any particular unusual patient outcome. The field may even have existed in a state of equipoise. Thinking back to my own years in medical school in the mid-1990s, I have clear memories of debates about the pejorative meanings of "non-compliant." The finding that grapefruit juice could interfere with commonly used antihypertensives received widespread attention. ${ }^{160}$ I have no recollection of pharmacogenetics being discussed at all.

Then something changed. As personalized medicine rose to prominence after 1999, physicians and entrepreneurs focused on genetic determinants of drug response. By 2010, leading health officials essentially declared the equivalence of personalized medicine and genetic medicine. ${ }^{161}$ Race-based medicine has followed closely on the heels of pharmacogenetics. ${ }^{162}$ A 2001 review described racial variations in the response to many important medications, include ACE inhibitors, antipsychotics, ß-blockers, calcium channel blockers, chemotherapy agents, diuretics, insulin, interferon, morphine, steroids, vasodilators, and warfarin. ${ }^{163}$ The potential of commercial innovation based on such differences is best demonstrated by the emergence of BiDil, a combination of two generic medications that were repackaged and approved for treatment of heart failure only in patients who self identify as black. ${ }^{164}$ Critics have argued that the advent of BiDil 
simultaneously represents both a cynical exploitation of loopholes in patent law and FDA policy, ${ }^{165}$ and our "durable preoccupation" with race. ${ }^{166}$ Despite the drug's commercial failure, there has been a "dramatic rise" since 2000 in biotechnology patents based on race and ethnicity. ${ }^{167}$ Some products have already come to market. Companies now sell race-specific vitamins, cosmetics, ancestry tests, and even walking shoes based on the putative unusual thickness of American Indian feet. ${ }^{168}$ The shift in balance towards genetic and racial explanations poses a fundamental question: what determines the relative importance given to possible explanations of biomedical phenomena?

It is not hard to explain the factors that favored the emergence of pharmacogenetics in the 1990s. Some operated at the broadest levels, with pharmacogenetics being but one example of the growing cultural fascination with all things genetic. ${ }^{169}$ Others were more specific. Sociologists have argued that the excited claims about expected future value have trumped concerns about cost and utility, such that researchers, regulators, investors, and patients all became enthusiastic despite lingering skepticism among clinicians. ${ }^{170}$ The status of genetics in therapeutics parallels its status in disease theories, where it also receives ever greater emphasis despite general awareness of both the limited yields of genetic analysis to date and the importance of other factors to disease susceptibility. ${ }^{171}$ Pharmacogenetics, like genetic medicine more broadly, remains very much a promissory science. ${ }^{172}$ More pragmatic factors have also played a role. Genetic explanations are biologically justifiable and convenient. The genetic sequence is 
seen as an invariant marker: measured once, it can guide treatment decisions throughout a patient's life. Genetic tests and technologies offer financial incentives not seen with interventions based on environmental exposures or non-compliance. Scientists seek funding, prestige, and marketable products through genetics. Regulators, investors, and patients encourage their pursuits.

Racial therapeutics have similarly strong appeals. Even as genetics has offered new modes of affinity, they have often become aligned with pre-existing ideas about race and ethnicity. ${ }^{173}$ Race-based practice is even more convenient than genetic practice: doctors need simply to look at a patient and profile accordingly. ${ }^{174}$ The resurgence of racial medicine has triggered understandable concern. Troy Duster, for instance, has warned that enthusiasm for genetics has led to the "molecular reinscription of race."175 Duana Fullwiley has described this in detail. When the National Institutes of Health established its Pharmacogenetics Research Network in 2000, its stated goal was individualized medicine. This soon gave way to a pragmatic and value-laden acceptance of race as a proxy for individual genetic variation. ${ }^{176}$ In response to the concerns, many advocates of pharmacogenetics and other forms of racial medicine reassure themselves by arguing that the use of race will be just a passing phase on the road to fully individualized treatment. ${ }^{177}$ However, the long presence of race in pharmacogenetics and the enduring popularity of race as a concept in science and society more generally suggest that its appeals will not fade quickly. The continued 
presence of race in medical practice will require on-going scrutiny from medical and social scientists. ${ }^{178}$

Even amid these many factors that facilitated the emergence of a racialized pharmacogenetics in the 1990s and 2000s, an appreciation of the longer history of the field deepens our understanding. Kalow's work began at a time when genetics did not preoccupy our worldview, before entrepreneurs had begun to funnel venture capital into the field, and before claims of the general relevance of pharmacogenetic alleles could even be attempted. Despite that, he had access to many strategies. Pharmacologic technology, from dibucaine numbers to the rhetorical power of probit plots, allowed him to craft simple but powerful arguments about the reality of difference and its genetic correlates. Analogies to differences between species and subspecies provided precedents for the expectation that human racial differences would exist. Appeals to the logic of natural selection explained why drug-metabolizing variants might have found their way into our genomes. A few cases, such as the distribution of isoniazid side effects seen in global tuberculosis campaigns or the terror of malignant hyperthermia, demonstrated the potential relevance of pharmacogenetics for health care and health policy. Once the claims were made by Kalow and others that pharmacogenetics was real and relevant, they had consequences: pharmacologists came to expect that genetic and racial variations would exist and they searched for them in what became a self-fulfilling prophecy. ${ }^{179}$ Kalow's work, along with that of Motulsky, Vesell, and others opened up the niche for pharmacogenetics and, 
within that, for race. This established a foundation of expectations on which later advocates could build their pharmacogenetic promises.

An appreciation of this history also alerts us to ways to broaden the discourse about personalized medicine. Seen in the longest perspective, the standardization of medical practice enabled by the model of specific etiology and specific therapy relied on an over-simplification (i.e., that all patients with a given disease could be treated in the same fashion), but one that brought vast gains in efficiency and increased the access of the world's populations to powerful treatments. The move is now away from standardization back towards individualization. But pharmacogenetics is another over-simplification. Focus on genetics leads to the neglect of other variables that influence drug response. In contrast to the dramatic scientific and commercial interest in pharmacogenetics, there is no similar energy for other ways of personalizing medicine. Where are the reviews or products that would help doctors assess diet and other environmental determinants of drug response? Where are the calls to understand patients' lives in a way that might allow physicians to prescribe feasible treatment plans? The rare exceptions that do exist demonstrate the potential power of social approaches to improve treatment outcome. ${ }^{180}$

Some observers have recently begun to suggest that the genetic moment has passed. ${ }^{181}$ Motulsky himself admitted in a New York Times profile that "the promise of pharmacogenetics is sometimes overhyped. There are people who think we'll be able to solve almost everything with an individualized prescription. We 
need more research, which will be expensive." ${ }^{182}$ Excitement has moved from genetics and genomics to epigenetics, proteomics, metabolonomics, and even microbiomics. It should also be possible to expand discussions of personalized medicine to include environment and behavior. Past experience suggests that genetics and race will both endure in medical practice, entrenched as they are in science, governance, and social relations. The promises and hopes that continue to circulate, however, deserve to be tempered by the many insights that can be gleaned from the history of pharmacogenetics. 
This work was supported by a grant from the Andrew W. Mellon Foundation that established the Center for the Study of Diversity in Science, Technology, and Medicine at MIT. It has benefitted from valuable feedback from audiences at MIT, Johns Hopkins University, the University of Minnesota, the University of California at Hastings, the University of California at San Francisco, the 2010 Gordon Cain conference at the Chemical Heritage Foundation, and Boston University. Detailed comments from Harry Marks, Stefan Helmreich, Anne Pollock, and several anonymous reviewers were especially useful in refining the arguments.

${ }^{1}$ W. Kalow, Pharmacogenetics: Heredity and the Response to Drugs (Philadelphia: W.W. Saunders Company, 1962).

${ }^{2}$ H.M. Schmeck, "Heredity Linked to Drug Effects," New York Times, 10 October 1962, 96; [Anonymous], "Medicine and Genetics," New York Times, 13 October 1962, 19.

${ }^{3}$ For a discussion of regulatory management of adverse drug reactions, see H. Marks, "Making Risks Visible: The Science \& Politics of Adverse Drug Reactions," in J.P. Gaudillière and V. Hess, ed., Ways of Regulating: Therapeutic Agents between Plants, Shops, and Consulting Rooms (Max-Planck-Institute für Wissenschaftsgeschichte, Preprint 363, Berlin, 2009), 105-22.

${ }^{4}$ M.A. Hamburg and F.S. Collins, "The Path to Personalized Medicine," N. Eng. J. Med., 2010, 363, 301-4. The concept of "personalized medicine" surfaced 
recently and dramatically. A PubMed search turns up 1560 hits (search performed 06/06/2011). Only two of these predate 1999.

${ }^{5}$ D. Nelkin and M.S. Lindee, The DNA Mystique: The Gene as a Cultural Icon, 2nd ed. (Ann Arbor: University of Michigan Press, 2004). See also: P. Rabinow, "Artificiality and Enlightenment: From Sociobiology to Biosociality," in J. Crary and S. Kwinter, Incorporations (Cambridge: Zone, 1992), 234-52; N. Rose, The Politics of Life Itself: Biomedicine, Power, and Subjectivity in the Twenty-First Century (Princeton: Princeton University Press, 2007).

${ }^{6}$ The key concepts of the field were laid out in 1957 by geneticist Arno Motulsky. See A. Motulsky, "Drug Reactions, Enzymes, and Biochemical Genetics," J. Am. Med. Assoc., 1957, 165, 835-7. The word itself was coined by Freidrich Vogel in 1959. See F. Vogel, "Moderne Probleme der Humangenetik," Ergeb. Inn. Med. Kinderheilkd, 1959, 12, 52-125. Kalow's 1962 Pharmacogenetics was the first book dedicated to the topic. Many reviews credit the seminal contributions of each: W. Kalow, "Pharmacogenetics: Past and Future," Life Sci., 1990, 47, 1385-97, 1389; B. Lerer, "Understanding Pharmacogenetics," Psychiatr. Times, 2003, 20, 37-9, 37; A. Hedgecoe and P. Martin, "The Drugs Don't Work: Expectations and the Shaping of Pharmacogenetics," Soc. Stud. Sci., 2003, 33, 327 64, 332. Motulsky is often singled out as the "father of pharmacogenomics." See C. Dreifus, "A Genetics Pioneer Sees a Bright Future, Cautiously: A Conversation with Arno Motulsky," New York Times, 29 April 2008. Similar claims, however, are also made for Kalow. See M. Easton, "Defining a Discipline: Werner Kalow, 
'Father of Pharmacogenetics,'" Edge -- Research, Scholarship and Innovation at the University of Toronto, 2002, 3; J. Viby-Mogensen, "Anesthesiology, the Birth of Pharmacogenetics, and Werner Kalow," Can. J. Anaesth., 2004, 51, 197-200. His 1962 book was "the seminal monograph in the emerging discipline of pharmacogenetics" (D.M. Grant and R.F. Tyndale, "In Memoriam: Werner Kalow, MD (1917-2008)," Pharmacogenet. Genomics, 2008, 18, 835-6, 835). The influence of Kalow can be gauged in many other ways. In 2001 he was awarded the Killam Prize, Canada's most distinguished award in science. See [Anonymous], “Werner Kalow, Ronald Melzack and Norbert Morgenstern, Recipients of \$100,000 Killam Prizes for 2001," News Release, The Canada Council for the Arts, 23 May 2001 (available at:

http://www.canadacouncil.ca/news/releases/2001/hs127240955723281250.htm). Kalow has received a form of Mertonian credit: a variant of butyrylcholinesterase has been named for him. See D. Gaffney and R.A. Campbell, "A PCR Based Method to Determine the Kalow Allele of the Cholinesterase Gene: The E1k Allele Frequency and Its Significance in the Normal Population," J. Med. Genet., 1994, 31, 248-50. The relative impact of Vogel, Motulsky, and Kalow can also be gauged by citation analysis from Web of Science. Vogel's 1959 piece has been cited 170 times. Motulsky's 1957 JAMA review has received 161 citations. Kalow's 1957 discussion of cholinesterase variants has received 681 citations; his 1962 book 422 citations. Searches performed 06/06/2011. 
${ }^{7}$ For instance, a search of the full runs of Isis, Bulletin of the History of Medicine, Journal of the History of Medicine and Allied Sciences, Journal of the History of Biology, and Studies in History and Philosophy of Biological and Biomedical Sciences, and Social Studies of Science, as well as a broader search of the JSTOR collections on Anthropology (55 journals), History (245 journals), and History of Science and Technology (25 journals) reveals very little work on Kalow. He is mentioned in passing in Hedgecoe, "Terminology and the Construction of Scientific Disciplines: The Case of Pharmacogenomics," Sci. Technol. Human Values, 2003, 28, 513-37; and Hedgecoe and Martin, "The Drugs Don't Work." His work receives occasional citation elsewhere (e.g., T. Johns, "The Chemical Ecology of Human Ingestive Behaviors," Annu. Rev. of Anthropol., 1999, 28, 27 50). I could find no sustained discussion of his work or career.

${ }^{8}$ Attempts to provide distinct and standardized definitions for pharmacogenetics and pharmacogenomics have not born fruit. For attempts, see R. Weinshilboum, "Inheritance and the Drug Response," N. Engl. J. Med., 2003, 348, 529-37; A. Hedgecoe, The Politics of Personalized Medicine: Pharmacogenetics in the Clinic (Cambridge: Cambridge University Press, 2004), 4. For a discussion, see D.S. Jones and R.H. Perlis, "Pharmacogenetics, Race, and Psychiatry," Harv. Rev. Psychiatry, 2006, 14, 92-116. In this paper I follow Kalow, and use "pharmacogenetics."

${ }^{9}$ The lack of attention to Kalow is emblematic of a more general foreshortening of the history of pharmacogenetics. Hedgecoe discusses the 
prehistory of pharmacogenomics in passing, spending three paragraphs on the period from 1957 to 1988 (Hedgecoe, "Terminology and the Construction of Scientific Disciplines," 332). Elsewhere he traces concern with race in pharmacogenomics back to just 1978 (A. Hedgecoe, "Bioethics and the Reinforcement of Socio-technical Expectations," Soc. Stud. of Sci., 2010, 40, 16386, 171). Sara Shostak's study of a related field, toxicogenomics, begins with the development of gene expression chips in the 1990s, missing the ways in which pharmacogenetics itself emerged out of work on toxicology in the 1940s. See S. Shostak, "The Emergence of Toxicogenomics: A Case Study of Molecularization," Soc. Stud. of Sci., 2005, 35, 367-403.

${ }^{10}$ For a parallel discussion of theory choice in the case of health inequalities, see D.S. Jones, Rationalizing Epidemics: Meanings and Uses of American Indian Mortality since 1600 (Cambridge: Harvard University Press, 2004); Jones, "The Persistence of American Indian Health Disparities," Am. J. Public Health, 2006, 96, 2122-34.

${ }^{11}$ Kalow has published several short autobiographies. For examples, see: Kalow, "Pharmacogenetics: Past and Future"; Kalow, "Life of a Pharmacologist or the Rich Life of a Poor Metabolizer," Pharmacol. Toxicol., 1995, 76, 221-7. He also wrote a longer autobiography, which remained unpublished when he gave me a copy in 2006 (Kalow, "A Colorful Life," 2006, in possession of the author). I interviewed him Kalow in 2006 (Jones and Kalow, Interview, 26-27 June 2006, recording and transcript in possession of the author). The narrative told here is 
drawn from these sources. He also allowed me to examine his personal papers. He had little from before 1965: he discarded most of his files when he returned to Germany for one year. His files since that date contained mostly reprints of articles and primary data from his research studies.

${ }^{12}$ Kalow, "A Colorful Life."

${ }^{13}$ Ibid.

${ }^{14}$ W. Kalow, "Cholerese durch synthetische Mittelung: II. Zur vergleichenden Physiologie und Pharmakologie der Gallensekretion," Naunyn Schmiedebergs Arch. Exp. Pathol. Pharmakol., 1949, 206, 43-8; W. Kalow, "Letalitatsbestimmungen und variation," Naunyn Schmiedebergs Arch. Exp. Pathol. Pharmakol., 1949, 207, 301-23.

${ }^{15}$ W. Kalow, "Zur Kenntnis der Butyrylcholin-Esterase in Serum von Mensch und Pferd," Naunyn Schmiedebergs Arch. Exp. Pathol. Pharmakol., 1952, 215, 370-77; Kalow, "Pharmacogenetics: Past and Future."

${ }^{16}$ Spectrophotometers, first developed in the late 19th century, only slowly became standard laboratory equipment. As late as the 1940s, they were rarely available at universities; researchers often had to build and maintain their own devices. See: P. Abir-Am, "The Discourse of Physical Power and Biological Knowledge in the 1930s: A Reappraisal of the Rockefeller Foundation's 'Policy' in Molecular Biology," Soc. Stud. Sci., 1982, 12, 341-82, esp. note 47; Y.M. Rabkin, "Technological Innovation in Science: The Adoption of Infrared Spectroscopy by Chemists," Isis, 1987, 78, 31-54, 40; and D.T. Zallen, "Redrawing the Boundaries 
of Molecular Biology: The Case of Photosynthesis," J. Hist. Biol., 1993, 26, 65-87, esp. $75-76$.

${ }^{17}$ Kalow, "Pharmacogenetics: Past and Future"; Kalow, "Life of a Pharmacologist."

${ }^{18}$ D.M. Aviado, T.H. Li, W. Kalow, C.F. Schmidt, G.L. Turnbull, G.W. Peskin, M.E. Hess, and A.J. Weiss, "Respiratory and Circulatory Reflexes from the Perfused Heart and Pulmonary Circulation of the Dog," Am. J. Physiol., 1951, 165, 261-77.

${ }^{19}$ This device has been called "the Model T of laboratory instruments." See R.D. Simoni, R.L. Hill, M. Vaughan, and H. Tabor, "A Classic Instrument: The Beckman DU Spectrophotometer and Its Inventor, Arnold O. Beckman," J. Biol. Chem., 2003, 278, 79-81, 79. During the 1930s and 1940s, the Rockefeller Foundation had actively promoted the development of spectrophotometry, as part of their effort to seed the life sciences with the technology and precision of the physical sciences. See Zallen, "The Rockefeller Foundation and Spectroscopy Research: The Programs at Chicago and Utrecht," J. Hist. Biol., 1992, 25, 67-89. After the war, device manufacturers worked actively to promote the use their spectrophotometers. Released in 1941, the Beckman DU Spectrophotometer became a lead player in this history. Simple and reliable to use, by the late 1940s, it was used by non-specialists in a wide range of research settings. See Rabkin, "Technological Innovation in Science," 48; Zallen, "Redrawing the Boundaries of Molecular Biology," 76. Despite the wide use of this device, it has received little 
attention from historians of science, and especially of medicine. The same search strategy described in note 8 turned up no relevant discussions of spectrophotometry beyond those already cited. Nor does it appear in some of the most important histories of molecular biology: M. Morange, A History of Molecular Biology (Cambridge: Harvard University Press, 1998); L.E. Kay, Who Wrote the Book of Life? A History of the Genetic Code (Stanford: Stanford University Press, 2000); S.D. Chadarevian, Designs for Life: Molecular Biology after World War II (Cambridge: Cambridge University Press, 2002). Spectrophotometry, however, has been used by a historian of medicine to test the efficacy of a historic treatment -antimony tartaric -- against cancer cells. See J. Duffin and B.G. Campling, "Therapy and Disease Concepts: The History (and Future?) of Antimony in Cancer," J. Hist. Med. Allied Sci., 2002, 57, 61-78.

${ }^{20}$ W. Kalow, "Hydrolysis of Local Anesthetics by Human Serum Cholinesterase," J. Pharmacol. Exp. Ther., 1952, 104, 122-34; Kalow, "Pharmacogenetics: Past and Future." This enzyme has been known by different names: serum cholinesterase, plasma cholinesterase, pseudocholinesterase, and butyrylcholinesterase. Kalow used the terms interchangeably, with a slight preference for serum cholinesterase.

${ }^{21}$ W. Kalow and K. Genest, "A Method for the Detection of Atypical Forms of Human Serum Cholinesterase: Determination of Dibucaine Numbers," Can. J. Biochem. Physiol., 1957, 35, 339-46. 
${ }^{22}$ W. Kalow, G.H.W. Lucas, and J.D. McColl, "Containers for Breath

Samples for Alcohol Analysis," in Proceedings of the 2nd International Congress on Alcohol and Road Traffic (Toronto, Canada, 1953), 137-8; G.H.W. Lucas, W.

Kalow, J.D. McColl, B.A. Griffith, and H.W. Smith, "Quantitative Studies of the Relationship between Alcohol Levels and Motor Vehicle Accidents," in

Proceedings of the 2nd International Congress on Alcohol and Road Traffic, 139-

42.

${ }^{23} \mathrm{~W}$. Kalow, "The Influence of $\mathrm{pH}$ on the Ionization and Biological Activity of d-Tubocurarine," J. Pharmacol. Exp. Ther., 1954, 110, 443-42.

${ }^{24}$ W. Kalow and H.A. Lindsay, "A Comparison of Optical and Manometric Methods for the Assay of Human Serum Cholinesterase," Can. J. Biochem. Physiol., 1955, 33, 568-74; Kalow, "Pharmacogenetics: Past and Future."

${ }^{25}$ W. Kalow and D.R. Gunn, "The Relation between Dose of Succinylcholine and Duration of Apnea in Man," J. Pharmacol. Exp. Ther., 1957, 120, 203-14.

${ }^{26}$ [Anonymous], "Abnormality Found in Blood of Long-term Mental Patients," Toronto Daily Star, 23 October 1954, 1.

${ }^{27}$ W. Kalow, "The Distribution, Destruction and Elimination of Muscle Relaxants," Anesthesiology, 1959, 20, 505-18; W. Kalow and D.R. Gunn, "Some Statistical Data on Atypical Cholinesterase of Human Serum," Ann. Hum. Gen., 1959, 23, 239-50. 
${ }^{28}$ H. Lehmann and E. Ryan, "The Familial Incidence of Low

Pseudocholinesterase Level," Lancet, 1956, 268, 124.

${ }^{29}$ Kalow, "A Colorful Life," 72.

${ }^{30}$ W. Kalow, "Familial Incidence of Low Pseudocholinesterase Level," Lancet, 1956, 268, 576-77.

${ }^{31}$ Kalow and Genest, "A Method for the Detection"; "Kalow and Gunn, "The Relations between Dose"; W. Kalow and N. Staron, "On Distribution and Inheritance of Atypical Forms of Human Serum Cholinesterase, as Indicated by Dibucaine Numbers," Can. J. Biochem. Physiol., 1957, 35, 1305-20.

${ }^{32}$ Kalow, Pharmacogenetics, 8-10. Many histories have been written about the emergence of this field. See: Abir-Am, "The Discourse of Physical Power"; Abir-Am, "The Politics of Macromolecules: Molecular Biologists, Biochemists, and Rhetoric," Osiris, 1992, 7, 164-91; L.E. Kay, The Molecular Vision of Life: Caltech, the Rockefeller Foundation, and the Rise of the New Biology (New York: Oxford University Press, 1993); R. Kohler, Lords of the Fly: Drosophila Genetics and the Experimental Life (Chicago: University of Chicago Press, 1994); Morange, A History of Molecular Biology; Kay, Who Wrote the Book of Life?; E.F. Keller, The Century of the Gene (Cambridge: Harvard University Press, 2000); Chadarevian, Designs for Life; B.J. Strasser, "Institutionalizing Molecular Biology in Post-War Europe: A Comparative Study," Stud. Hist. Phil. Biol. Biomed. Sci., 2002, 33, 515-46; N.C. Comfort, The Tangled Field: Barbara McClintock's Search for the Patterns of Genetic Control (Cambridge: Harvard University Press, 2003); M.S. Lindee, 
Moments of Truth in Genetic Medicine (Baltimore: Johns Hopkins University Press, 2005).

${ }^{33}$ G.E.W. Wolstenholme and C.M. O'Connor, eds., Ciba Foundation Symposium on Human Biochemical Genetics (London: Churchill, 1959).

${ }^{34}$ Kalow, Pharmacogenetics.

${ }^{35}$ Ibid.

${ }^{36}$ A.E. Garrod, "The Incidence of Alkaptonuria: A Study in Chemical Individuality," Lancet, 1902, 160, 1616-20.

${ }^{37}$ Kalow, Pharmacogenetics, 1.

${ }^{38}$ Ibid., 200.

${ }^{39}$ Motulsky, "Drug Reactions," 835. Motulsky specifically cited the case of hemolytic anemia after primaquine prophylaxis, and Lehmann and Ryan's report about cholinesterase variants (citing Kalow as a confirmation of this finding). Motulsky, however, remained cautious, noting that the adverse reactions were "possibly caused by genetic enzymatic defects" and that "No proved examples due to genetic defects exist in man" (836).

${ }^{40}$ Vogel, "Moderne Probleme der Humangenetik." Pharmacogenetics took shape with the work of three men -- Kalow, Motulsky, and Vogel -- who had lived under Nazi rule in the 1930s. While facile arguments are tempting, the situation is complex. Each had very different experiences with Nazis. Kalow, as noted above, completed his medical training before active duty as a naval officer. Vogel was drafted after completing secondary school, served in the army, and then trained in 
medicine in Germany after the war. See K. Sperling, "Obituary: Prof. Dr. med. Dr. h.c. Friedrich Vogel," Hum. Genet., 2007, 120, 755-7. Motulsky, Jewish, had tried to flee Germany before the war. One of the refugees on the S.S. St. Louis, he reached Havana harbor in 1939 only to be turned back to Europe. He spent nearly a year in internment camps before escaping to the United States, where he trained. See [Anonymous], "Profile of Dr. Motulsky -- Holding Out Hope in a Cruel World: Geneticist Arno Motulsky Recalls Wartime Europe," UW Medicine, 2002, 25, 9-12.

${ }^{41}$ When Bernard Brodie introduced the First International Pharmacological Meeting, held in Stockholm in August 1961, he singled out Kalow's work on the genetics of drug response: "Individual differences in drug metabolism pose a fascinating problem. Dr. Kalow has made a notable beginning by showing that some subjects have a hereditary defect of the enzyme that hydrolyzes succinylcholine. Studies along a similar vein might help to explain the wide variability from person to person in rates of metabolism of other drugs." See B.B. Brodie, "Introduction," in Brodie and E.G. Erdös, eds., Metabolic Factors Controlling Duration of Drug Action (New York: Macmillan Company, 1962), xiiixviii, xvii.

${ }^{42}$ [Anonymous], "Medicine and Genetics."

${ }^{43}$ For instance, the Laboratory of Clinical Pharmacology at NIH, led by Axelrod and Brodie, used spectrophotometers in many similar ways. For examples see: J. Axelrod and J. Reichenthal, "The Fate of Caffeine in Man and a Method for Its Estimation in Biological Material," J. Pharmacol. Exp. Ther., 1953, 107, 519-523; 
S. Udenfriend, D.E. Duggan, B.M. Vasta, and B.B. Brodie, "A Spectrophotofluorometric Study of Organic Compounds of Pharmacological Interest," J. Pharmacol. Exp. Ther., 1957, 120, 26-32. For an example from the University of Chicago, see A. Ganz, F.E. Kelsey, and E.M.K. Geiling, "Excretion and Tissue Distribution Studies on Radioactive Nicotine," J. Pharmacol. Exp. Ther., $1951,103,209-14$.

${ }^{44}$ Kalow and Gunn, "The Relations between Dose," 205. Kalow's procedure fits well with Rheinberger's account of an experimental system. See H.J. Rheinberger, Toward A History of Epistemic Things: Synthesizing Proteins in the Test Tube (Stanford: Stanford University Press, 1997). Kalow did not set out to demonstrate the genetics of drug action. Instead he simply hoped to demonstrate that his spectrophotometer could measure accurately esterase action in patients with normal and low rates of enzyme activity. The DN began as an epistemic thing, an attempt to quantify reliably enzyme activity regardless of enzyme concentration. As Kalow gained experience, it stabilized into a technical object which could be used to make novel arguments about serum cholinesterase and its heritability.

${ }^{45}$ This work fits well with how Rheinberger has defined molecular biology: a field concerned with "creating the technical means for an extracellular representation of intracellular configurations" (Rheinberger, "Beyond Nature and Culture: A Note on Medicine in the Age of Molecular Biology," Sci. Context, 1995, $8,249-263,249)$. For a more general description of the role of such inscription 
devices, especially in the biomedical sciences, see B. Latour and S. Woolgar, Laboratory Life: The Construction of Scientific Facts, 2nd ed. (Princeton: Princeton University Press, 1986); B. Latour, "Visualization and Cognition: Drawing Things Together," Knowledge \& Society, 1986, 6, 1-40.

${ }^{46}$ D.J. Kevles, In the Name of Eugenics: Genetics and the Uses of Human Heredity (Berkeley: University of California Press, 1986); Kohler, Lords of the Fly (1994).

${ }^{47}$ For an important example, see J.V. Neel, "The Inheritance of Sickle Cell Anemia," Science, 1949, 110, 64-66.

${ }^{48}$ The logic of this argument resembled that used by Linus Pauling in 1949 when he analyzed the relationship between hemoglobin structure and function. See L. Pauling, H.A. Itano, S.J. Singer, and I.C. Wells, "Sickle Cell Anemia, a Molecular Disease," Science, 1949, 110, 543-8. Using gel electrophoresis, Pauling showed the normal and sickle hemoglobin behaved differently at a $\mathrm{pH}$ of 6.9. This difference in their ionization behavior had to reflect a difference in their protein structure. Since Pauling believed that sickle cell trait was genetic, he concluded that genes functioned by determining the structure of proteins. For a discussion, see B.J. Strasser, "Sickle Cell Anemia, a Molecular Disease," Science, 1999, 286, 1488-1490; Strasser, “Linus Pauling's 'Molecular Diseases': Between History and Memory," Am. J. Med. Genet, 2002, 115, 83-93. Since Kalow, by 1957, believed that genes determined the structure of proteins, he interpreted evidence of structural difference as evidence of genetic control. I assume, but cannot prove, 
that Kalow was aware of Pauling's work. An analysis of the citations in Kalow's publications through 1962, as indexed by Web of Science, reveals no citations to Pauling, but this provides only limited insight into what Kalow did or did not know.

${ }^{49}$ Kalow and Staron, "On Distribution and Inheritance."

${ }^{50}$ Neel, "The Inheritance"; Pauling and others, "Sickle Cell Anemia";

Strasser, "Linus Pauling's 'Molecular Diseases.'"

${ }^{51}$ For histories of molecular biology, see note 32. Zallen has critiqued the narrow focus of historians on the information camp and on the structure-function camp. See Zallen, "Redrawing the Boundaries of Molecular Biology."

${ }^{52}$ These devices figure into nearly every history of molecular biology. The Rockefeller Foundation actively supported the transfer of research technologies and played an important role in the emergence of many of the early centers of molecular biology. See Abir-Am, "The Discourse of Physical Power," 344-5; Zallen, "The Rockefeller Foundation and Spectroscopy Research," 67-8. When the Foundation began to fund Pauling's work at Cal Tech, he requested all sorts of equipment, including microscopes, polarimeters, refractometers, microphotometers. One of his earliest requests was for a spectrophotometer. See Kay, The Molecular Vision of Life, 155.

${ }^{53}$ Zallen, "The Rockefeller Foundation and Spectroscopy Research"; Zallen, "Redrawing the Boundaries of Molecular Biology"; T. van Helvoort, "Institutionalizing Biochemistry: The Enzyme Institute at the University of Wisconsin," J. Hist. Med. Allied Sci., 2002, 57, 449-479. 
${ }^{54}$ G. Montalenti, "Chariman's Opening Remarks," in Wolstenholme and O'Connor, eds., Ciba Foundation Symposium on Human Biochemical Genetics, 38,6 .

${ }^{55}$ L. Penrose, "Genetical Analysis in Man," in Wolstenholme and O'Connor, eds., Ciba Foundation Symposium on Human Biochemical Genetics, 9-22, 13.

${ }^{56}$ L. Cavalli-Sforza, Comment on Penrose, "Genetical Analysis in Man," 22.

${ }^{57}$ Kalow, "Cholerese durch synthetische Mittelung"; Kalow, "Letalitatsbestimmungen und variation."

${ }^{58}$ Kalow, "Pharmacogenetics: Past and Future."

${ }^{59}$ Kalow, "Zur Kenntnis der Butyrylcholin-Esterase."

${ }^{60}$ Aviado and others, "Respiratory and Circulatory Reflexes."

${ }^{61}$ Kalow, "The Influence of $\mathrm{pH} . "$

${ }^{62}$ Kalow, "A Colorful Life," 61.

${ }^{63}$ Kalow, Pharmacogenetics, 54.

${ }^{64}$ P.B. Sawin and D. Glick, "Atropinesterase, a Genetically Determined Enzyme in the Rabbit," Proc. Natl. Acad. Sci. U.S.A., 1943, 29, 55-9, 56.

${ }^{65}$ W. Kalow, "Esterase Action," Biochem. Pharmacol., 1961, 8 (Abstract \#375), 110-1; W. Kalow, "Relaxants," in E.M. Papper and R.J. Katz, eds., Uptake and Distribution of Anesthetic Agents (New York: McGraw Hill, 1963), 302-13.

${ }^{66}$ W. Kalow, "Pharmacogenetics and the Predictability of Drug Responses," in G.E.W. Wolstenholme and R. Porter, eds., Ciba Foundation Symposium on Drug Responses in Man (London: J. \& A. Churchill, Ltd., 1967), 220-33, 231. 
${ }^{67}$ Kalow, "Relaxants," 308.

${ }^{68}$ Kalow, Pharmacogenetics, 60.

${ }^{69}$ Ibid., 59.

${ }^{70}$ W. Kalow, "Pharmacogenetics in Animals and Man," Ann. N. Y. Acad. Sci., 1968, 151: 694-8, 696.

${ }^{71}$ Motulsky, "Drug Reactions," 836.

72 Brodie, "Introduction," xvii.

${ }^{73}$ Kalow, "Familial Incidence."

${ }^{74}$ Kalow and Staron, "On Distribution and Inheritance."

${ }^{75}$ Kalow, Pharmacogenetics, 92-93.

${ }^{76}$ A.C. Allison, "Protection Afforded by Sickle Cell Trait against Subtertian Malaria Infection," Br. Med. J., 1954, 1, 290-4.

77 Montalenti, "Chairman's Opening Remarks" (1959), 13.

78 lbid., 13-14.

${ }^{79}$ Motulsky, "Drug Reactions," 836.

${ }^{80}$ Brodie, "Introduction," xvi.

${ }^{81}$ B.B. Brodie, "Phylogenetic Origin of Detoxification Mechanisms,"

Biochem. Pharmacol., 1961, 8, 167.

${ }^{82}$ Kalow, "Pharmacogenetics in Animals and Man," 694.

${ }^{83}$ S.J. Gould, "Darwinian Fundamentalism," New York Rev. Books, 12 June 1997; Gould, "Evolution: The Pleasures of Pluralism," New York Rev. Books, 26 June 1997. 
${ }^{84}$ S. Pinker, with a reply by Gould, "Evolutionary Psychology: An Exchange," New York Rev. Books, 9 October 1997.

${ }^{85}$ W. Kalow and H. Kalant, "Evolutionary Psychology: An Exchange," New York Rev. Books, 9 October 1997. See also Kalow, "Phamacogenetics and Evolution," Pharmacogenetics, 2000, 10: 1-3. Kalow did, however, acknowledge one caveat about mechanisms of natural selection for pharmacogenetic traits: "The genes which determine the pattern and adaptability of drug-metabolising enzymes must be expected to be under different kinds of selection pressure than the genes which convey visible, racial characteristics. Physical appearance may certainly affect mating instincts but it is reasonable to assume that there was never ever a marriage on the basis of the partner's rates of antipyrine metabolism." See: W. Kalow, "Ethnic Differences in Drug Metabolism," Clin. Pharmacokinet, 1982, 7, $373-400,374$.

${ }^{86}$ Gould, "Evolutionary Psychology: An Exchange," New York Rev. Books, 9 October 1997.

${ }^{87}$ Kalow, Pharmacogenetics.

${ }^{88}$ H.A. Paskind, "Some Differences in Response to Atropine in White and Coloured Races," J. Lab. Clin. Med., 1921, 7, 104-8.

${ }^{89}$ K.K. Chen and E.J. Poth, "Racial Differences as Illustrated by the Mydriatic Action of Cocaine, Euphthalmine, and Ephedrine," J. Pharm. Exp. Ther., 1929, 36, 429-45; Kalow, Pharmacogenetics, 206-208.

${ }^{90}$ W. Kalow, "Genetic Aspects of Drug Safety," Appl. Ther., 1966, 8, 44-7. 
${ }^{91}$ A.S. Alving, J. Arnold, D.H. Robinson, P.L. Garrison, D.D. Hankey, W.G.

Coker, W.N. Donovan, B. Jastremski, G.R. Coatney, R. Jones, C.B. Clayman, R.S. Hockwald, E.H. Yount, and J.H. Edgcomb, "Status of Primaquine," J. Am. Med. Assoc., 1952, 149, 1558-70; P.E. Carson, C.L. Flanagan, C.E. Ickes, and A.S. Alving, "Enzymatic Deficiency in Primaquine-sensitive Erythrocytes," Science, $1956,124,484-5$

${ }^{92}$ Kalow, Pharmacogenetics, 118-119, table 22.

${ }^{93}$ H.B. Hughes, J.P. Biehl, A.P. Jones, and L.H. Schmidt, "Metabolism of Isoniazid in Man as Related to the Occurrence of Peripheral Neuritis," Am. Rev. Tuberc., 1954, 70, 266-73; D.A. Price Evans, K.A. Manley, and V.A. McKusick, "Genetic Control of Isoniazid Metabolism in Man," Br. Med. J., 1960, 1, 485-91;

Kalow, Pharmacogenetics, 98-99; A.P. Dufour, R.A. Knight, and H.W. Harris, "Genetics of Isoniazid Metabolism in Caucasian, Negro, and Japanese Populations," Science, 1964, 145: 391; D.E. Drayer and M.M. Reidenberg, "Clinical Consequences of Polymorphic Acetylation of Basic Drugs," Clin. Pharmacol. Ther., 1977, 22, 251-8.

${ }^{94}$ W. Kalow, "Unusual Responses to Drugs in Some Hereditary Conditions," Can. Anaesth. Soc. J., 1961, 8, 43-52.

${ }^{95}$ Kalow, Pharmacogenetics, 119-121.

${ }^{96}$ Motulsky, "Drug Reactions," 835 (example), 836 (quotation).

${ }^{97}$ For a discussion, see J. Reardon, "The Human Genome Diversity Project: A Case Study in Coproduction," Soc. Stud. Sci., 2001, 31, 357-88; Reardon, Race 
to the Finish: Identity and Governance in an Age of Genomics (Princeton: Princeton University Press, 2005), esp. pp. 17-44.

${ }^{98}$ Kalow, "A Colorful Life," 31.

${ }^{99}$ Kalow and Gunn, "Some Statistical Data," 244.

${ }^{100}$ Ibid., 247.

${ }^{101}$ W. Kalow, "The Variants of Human Pseudocholinesterase," in F.

Linneweh, ed., Erbliche Stoffwechselkrankheiten: Genetic Defects of Biologically

Active Proteins (Munich: Urban \& Schwarzenberg, 1961), 541-6, 544.

${ }^{102}$ S.J. Gould, "Why We Should Not Name Human Races -- A Biological

View," in Ever Since Darwin: Reflections in Natural History (New York: W.W.

Norton \& Company, Inc., 1977), 231-6; J. Marks, What It Means To Be 98\%

Chimpanzee: Apes, People, and Their Genes (Berkeley: University of California

Press, 2002).

${ }^{103}$ Kalow, Pharmacogenetics, 211.

${ }^{104}$ Kohler, Lords of the Fly; A. Creager, The Life of a Virus: Tobacco Mosaic

Virus as an Experimental Model, 1930-1965 (Chicago: University of Chicago Press, 2002); K. Rader, Making Mice: Standardizing Animals for American Biomedical Research, 1900-1955 (Princeton: Princeton University Press, 2004).

${ }^{105}$ Brodie, "Introduction," xvii.

${ }^{106}$ W. Kalow, "Genetic Differences in Drug Metabolism," Ann. N. Y. Acad.

Sci., 1963, 104, 894-904, 902 
107 Schmeck, "Heredity Linked to Drug Effects"; [Anonymous], "Medicine and Genetics."

${ }^{108}$ Kalow, "Pharmacogenetics: Past and Future."

${ }^{109}$ M.A. Denborough and R.R.H. Lovell, "Anesthetic Deaths in a Family," Lancet, 1960, 276, 45; B.A. Britt and W. Kalow, "Hyperrigidity and Hyperthermia Associated with Anesthesia," Ann. N. Y. Acad. Sci., 1968, 151, 947-58; B.A. Britt, W.G. Locher, and W. Kalow, "Hereditary Aspects of Malignant Hyperthermia," Clin. Pharmacol. Ther., 1969, 16, 89-98; W. Kalow, B.A. Britt, M.E. Terreau, and C. Haist, "Metabolic Error of Muscle Metabolism after Recovery from Malignant Hyperthermia," Lancet, 1970, 296, 895-8; L.K. Altman, "Test Helps Prevent Anesthesia Peril," New York Times, 30 May 1974, 25.

${ }^{110}$ B.A. Britt and W. Kalow, "Malignant Hyperthermia - A Statistical Review," Can. Anaesth. Soc. J., 1970, 17: 293-315, on p. 294.

${ }^{111}$ B.A. Britt and W. Kalow, "Malignant Hyperthermia - Aetiology Unknown!" Clin. Pharmacol. Ther., 1970, 17: 316-30; B.A. Britt, W. Kalow, A. Gordon, J.G. Humphrey, and N.B. Rewcastle, "Malignant Hyperthermia: An Investigation of Five Patients," Clin. Pharmacol. Ther., 1973, 20, 431-67.

${ }^{112}$ Kalow, "Genetic Differences" (1963); W. Kalow, "Genetic Factors in Relation to Drugs," Ann. Rev. Pharmacol., 1965, 5, 9-26.

${ }^{113}$ W. Kalow, "Susceptibility to Drug Action," in M. Bartelos, ed., Genetics in Medical Practice (Philadelphia: J.B. Lippincott Company, 1968), 219-29. 
${ }^{114}$ E.S. Vesell and J.G. Page JG, "Genetic Control of Drug Levels in Man:

Phenylbutazone," Science, 1968, 159: 1479-80; Vesell and Page, "Genetic Control of Drug Levels in Man: Antipyrine," Science, 1968, 161: 72-3; Vesell, "Intraspecies Differences in Frequency of Genes Directly Affecting Drug Disposition: The Individual Factor in Drug Response," Pharmacol. Rev., 1979, 30, 555-63; Kalow, "Pharmacogenetics: Past and Future."

${ }^{115}$ N.E. Simpson and W. Kalow, "Comparisons of Two Methods for Typing of Serum Cholinesterase and Prevalence of its Variants in a Brazilian Population," Amer. J. Hum. Gen., 1965, 17, 156-62.

${ }^{116}$ Simpson and Kalow, "Comparisons of Two Methods," 160.

117 W. Kalow, "The Metabolism of Xenobiotics in Different Populations,"

Can. J. Physiol. Pharmacol., 1982, 60, 1-12; Kalow, "Ethnic Differences."

${ }^{118}$ W. Kalow, "Individual Variation in Drug Metabolism as Cause of Drug Toxicity," in B.B. Brodie and J.R. Gillette, eds., Drugs and Enzymes, volume 4 in Proceedings of the Second International Pharmacological Meeting (New York: Pergamon Press, 1965), 245-55.

${ }^{119}$ W. Kalow, ed., for the WHO - Scientific Group, Pharmacogenetics (World Health Organization Technical Report Serial \#524, 1973), 1-40, 27. 120 Ibid., 36.

${ }^{121}$ W. Kalow and A.E. Leblanc, "Implications of Psychopharmacogenetics Research," in B.E. Eleftheriou, ed., Psychopharmacogenetics (New York: Plenum Publishing Corporation, 1975), 33-42, 39. 
${ }^{122}$ B.K. Tang, T. Inaba, and W. Kalow, "N-Hydroxyamobarbital, The Second Major Metabolite of Amobarbital in Man," Drug Metab. Dispos., 1975, 3: 479-86;

L. Endrenyi, T. Inaba, and W. Kalow, "Genetic Study of Amobarbital Elimination Based on its Kinetics in Twins," Clin. Pharmacol. Ther., 1976, 20: 701-14.

${ }^{123}$ W. Kalow, B.K. Tang, D. Kadar, and T. Inaba, "Distinctive Patterns of Amobarbital Metabolites in Man," Clin. Pharmacol. Ther., 1978, 24, 576-82.

${ }^{124}$ Ibid., 580.

${ }^{125}$ Ibid., 582.

${ }^{126}$ W. Kalow, L. Endrenyi, T. Inaba, D. Kadar, and B. Tang, "Pharmacogenetic Investigation of Amobarbital Disposition," in P. DucheneMarullaz, ed. Advances in Pharmacology and Therapeutics (New York: Pergamon Press, 1978), 31-40, 38.

${ }^{127}$ W. Kalow, B.K. Tang, D. Kadar, L. Endrenyi, and F.Y. Chan, "A Method to Study Drug Metabolism in Populations: Racial differences in Amobarbital Metabolism," Clin. Pharmacol. Ther., 1979, 26, 766-76.

128 Ibid., 774. In a curious twist, Kalow moved from this finding of a racial difference in humans to a search for species-level variation in mammals: "Such a comparison appeared to be worthwhile in view of the interethnic differences in the metabolite pattern of amobarbital." See: B.K. Tang, A.A. Grey, P.A.J. Reilly, and W. Kalow, "Species Differences of Amobarbital Metabolism:

Dihydroxyamobarbital Formation," Can. J. Physiol. Pharmacol., 1980, 58, 1167-9, 1167. Kalow's team looked at Wistar rats, Swiss mice, hamsters, guinea pigs, two 
men, and one mongrel dog. They found a dihydroxy metabolite in the other mammals, but no glucosidation, a discrepancy "not understood at this time" (1168).

${ }^{129}$ Kalow and others, "A Method to Study."

${ }^{130}$ W. Kalow, S.V. Otton, D. Kadar, L. Endrenyi, and T. Inaba, "Ethnic Difference in Drug Metabolism: Debrisoquine 4-Hydroxylation in Caucasians and Orientals," Can. J. Physiol. Pharmacol., 1980, 58: 1142-4, 1142.

${ }^{131}$ Kalow, "Pharmacogenetics: Some New Challenges," Pharmacy International, 1980, 1, 113-5, on p. 114.

${ }^{132}$ Kalow and others, "Ethnic Difference," 1142.

133 Ibid., 1142.

${ }^{134}$ T. Inaba, H. Uchino, D. Kadar, and W. Kalow, "Antipyrine Metabolites in Two Populations," Res. Commun. Chem. Pathol. Pharmacol., 1981, 32, 235-44, 235.

${ }^{135}$ T. Inaba, M. Lucassen, and W. Kalow, "Antipyrine Metabolism in the Rat by Three Hepatic Monooxygenases," Life Sci., 1980, 26, 1977-83, on p. 1977.

${ }^{136}$ Ambivalence about the use of race in medical research and publishing persists today. For a prominent debate in one journal, see E.G. Burchard, E. Ziv, N. Coyle, S.L. Gomez, H. Tang, A.J. Karter, J.L. Mountain, E.L. Pérez-Stable, D. Sheppard, and N. Risch, "The Importance of Race and Ethnic Background in Biomedical Research and Clinical Practice," N. Engl. J. Med., 2003, 348, 1170-5; R.S. Cooper, J.S. Kaufman, and W. Ward, "Race and Genomics," N. Engl. J. Med., 
2003, 348, 1166-70; E.G. Phimister, "Medicine and the Racial Divide," N. Engl. J.

Med., 2003, 348, 1081-2. For an overview of the debates, see S. Epstein, Inclusion: The Politics of Difference in Medical Research (Chicago: University of Chicago Presss, 2007). For specific discussions by social scientists of journal policies, see: P. Sankar and M.K. Cho, "Toward a New Vocabulary of Human Genetic Variation," Science, 2002, 298, 1337-8; J. Stevens, "Racial Meanings and Scientific Methods: Changing Policies for NIH-Sponsored Publication Reporting Human Variation," J. Health Polit Policy Law, 2003, 28, 1033-87; G.T.H. Ellison, A. Smart, R. Tutton, S.M. Outram, R. Ashcroft, and P. Martin, "Racial Categories in Medicine: A Failure of Evidence-Based Practice?" PLoS Med., 2007, 4,1434-6; A. Smart, R. Tutton, G.T.H. Ellison, P. Martin and R. Ashcroft, "The Standardization of Race and Ethnicity in Journal Editorials and UK Biobanks," Soc. Stud. Sci., 2008, $38,407-423$.

${ }^{137}$ Kalow, "Ethnic Differences."

${ }^{138}$ Kalow, "Pharmacogenetics," 114.

${ }^{139}$ Kalow, "The Metabolism of Xenobiotics," 2.

${ }^{140}$ W. Kalow, H.W. Goedde, and D.P. Agarwal, eds., Ethnic Differences in Reactions to Drugs and Xenobiotics (New York: Alan R. Liss, Inc., 1986).

${ }^{141}$ W. Kalow, "Race and Therapeutic Drug Response," N. Engl. J. Med., 1989, 320, 588-590, 589.

${ }^{142}$ K. Nakamura, F. Goto, W.A. Ray, C.B. McAllister, E. Jacqz, G.R. Wilkinson, and R.A. Branch, "Interethnic Differences in Genetic Polymorphism of 
Debrisoquin and Mephenytoin Hydroxylation between Japanese and Caucasian Populations," Clin. Pharmacol. Ther., 1985, 38: 402-8; L. Bertilsson, Y.Q. Lou, Y.L. Du, Y. Liu, T.Y. Kuang, X.M. Liao, K.Y. Wang, J. Reviriego, L. Iselius, and F. Sjöqvist, "Pronounced Differences between Native Chinese and Swedish Populations in the Polymorphic Hydroxylations of Debrisoquin and Smephenytoin," Clin. Pharmacol. Ther., 1992, 51, 388-97.

${ }^{143}$ Kalow, "Race and Therapeutic Drug Response" (1989); Kalow, "Pharmacogenetics: Past and Future" (1990); W. Kalow, "Interethnic Variation of Drug Metabolism," Trends Pharmacological Sciences, 1991, 12, 102-7; K.M. Lin, R.E. Poland, and D. Anderson, "Psychopharmacology, Ethnicity, and Culture," Transcultural Psychiatric Research, 1995, 32, 3-40; W.E. Evans and M.V. Relling, "Pharmacogenomics: Translating Functional Genomics into Rational Therapeutics," Science, 1999, 286, 487-90; Weinshilboum, "Inheritance and the Drug Response" (2003).

${ }^{144}$ L. Bertilsson, "Geographical/Interracial Differences in Polymorphic Drug Oxidation: Current State of Knowledge of Cytochromes P450 (CYP) 2D6 and 2C19," Clinical Pharmacokinetic Concepts 1995, 29, 192-209. The broadening popularity of race and ethnicity in pharmacogenetics at this time exemplifies the enduring popularity of race and race stereotypes in science. See S.L. Gilman, Difference and Pathology: Stereotypes of Sexuality, Race, and Madness (Ithaca: Cornell University Press, 1985); M. Omi and H. Winant, Racial Formation in the United States: from the 1960s to the 1990s, 2nd ed. (New York: Routledge, 1994). 
${ }^{145}$ W. Kalow, "Genetic Comparisons of Populations," submitted to Varsity (University of Toronto), 2002, in the personal papers of W. Kalow.

${ }^{146}$ W. Kalow, "Should a Physician Consider a Patient's Ethnic Background?" submitted to the New England Journal of Medicine, 2002, in the personal papers of W. Kalow; M.B. Hamel, Letter to Werner Kalow, 30 August 2002, in the personal papers of Werner Kalow.

${ }^{147}$ W. Kalow, "Medical Practice, Race, and Drug Use," Clin. Pharmacol. Ther., 2003, 73, 132-4.

${ }^{148}$ H.L. Richardson, A.R. Stier, and E. Borsos-Natch-Nebel, “Liver Tumor Inhibition and Adrenal Histologic Respones in Rats to which 3'-methyl-4-dimethylaminoazo-benzene and 20-methylcholanthrene Were Simultaneously Administered," Cancer Research, 1952, 12, 356-61; A.H. Conney and J.J. Burns, "Metabolic Interactions among Environmental Chemicals and Drugs," Science, 1972, 178, 576-86; Conney, "Induction of Drug-metabolizing Enzymes: A Path to the Discovery of Multiple Cytochromes P450," Annual Review of Pharmacology and Toxicology, 2003, 43, 1-30.

${ }^{149}$ Conney and Burns, "Metabolic Interactions" (1972); E.J. Pantuck, R. Kuntzman, and A.H. Conney, "Decreased Concentration of Phenacetin in Plasma of Cigarette Smokers," Science, 1972, 175, 1248-50; A.H. Conney, E.J. Pantuck, K.C. Hsiao, W.A. Garland, K.E. Anderson, A.P. Alvares, and A. Kappas, "Enhanced Phenacetin Metabolism in Human Subjects Fed Charcoal-broiled Beef," Clin. Pharmacol. Ther., 1976, 20, 633-42. 
${ }^{150}$ J. Axelrod, "An Unexpected Life in Research," Annual Review of

Toxicology, 1988, 28, 1-23; Conney, "Induction of Drug-metabolizing Enzymes" (2003)

${ }^{151}$ A. Kappas, K.E. Anderson, A.H. Conney, A.P. Alvares, "Influence of Dietary Protein and Carbohydrate on Antipyrine and Theophylline Metabolism in Man," Clin. Pharmacol. Ther., 1976, 20, 643-53; E.J. Pantuck, K.C. Hsiao, A.H. Conney, W.A. Garland, A. Kappas, K.E. Anderson, and P. Alvares, "Effect of Charcoal-broiled Beef on Phenacetin Metabolism in Man," Science, 1976, 194, 1055-7; Conney and others, "Enhanced Phenacetin Metabolism"; A.P. Alvares, K.E. Anderson, A.H. Conney, and A. Kappas, "Interactions between Nutritional Factors and Drug Biotransformations in Man," Proc. Natl. Acad. Sci. U.S.A., 1976, 73, 2501-4; A.H. Conney, E.J. Pantuck, R. Kuntzman, A. Kappas, K.E. Anderson, and A.P. Alvares, "Nutrition and Chemical Biotransformations in Man," Clin. Pharmacol. Ther., 1977, 22, 707-20; A.P. Alvares, E.J. Pantuck, K.E. Anderson. A. Kappas, and A.H. Conney, "Regulation of Drug Metabolism in Man by Environmental Factors," Drug Metab. Rev., 1979, 9, 185-205; E.J. Pantuck, C.B. Pantuck, K.E. Anderson, L.W. Wattenberg, A.H. Conney, and A. Kappas, "Effect of Brussels Sprouts and Cabbage on Drug Conjugation," Clin. Pharmacol. Ther., 1984, 35: 161-9.

${ }^{152}$ A.P. Alvares, A. Kappas, J.L. Eiseman, K.E. Anderson, C.B. Pantuck, E.J. Pantuck, K.C. Hsiao, W.A. Garlan, and A.H. Conney, "Intraindividual Variation in Drug Disposition," Clin. Pharmacol. Ther., 1979, 26, 407-19. 
${ }^{153}$ R.A. Branch, S.Y. Salih, M. Homeida, "Racial Differences in Drug Metabolizing Ability: A Study with Antipyrine in the Sudan," Clin. Pharmacol. Ther., 1978, 24, 283-6. When a group of Sudanese immigrants came to England and "largely assimilated into an English style of life and eating habits," they metabolized antipyrine rapidly, more like their English neighbors than their Sudanese cousins (285).

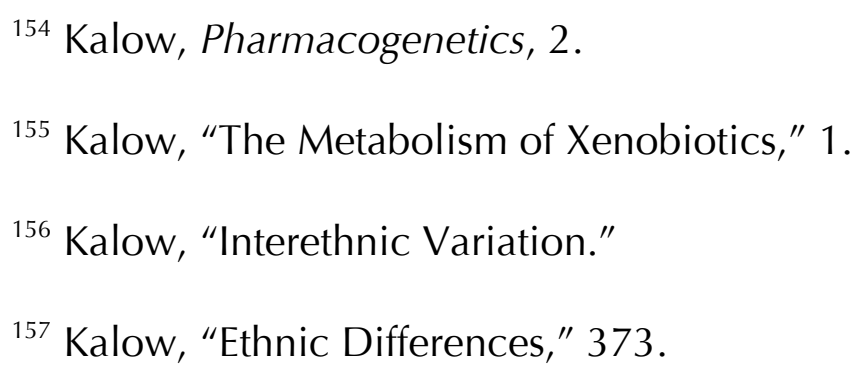

${ }^{159}$ D.W.T. Haynes and D.L. Sackett, Compliance in Health Care (Baltimore, Johns Hopkins University Press, 1979); D.S. Jones, "Technologies of Compliance: Surveillance of Self-administration of Tuberculosis Treatment, 1956-1966," History and Technology, 2001, 17, 279-318; J.A. Greene, "Therapeutic Infidelities: Noncompliance Enters the Medical Literatures, 1955-1975," Soc. Hist. Med., 2004, $17,327-43$

160 D.G. Bailey, J.D. Spence, C. Munoz, and J.M. Arnold, "Interaction of Citrus Juices with Felodipine and Nifedipine," Lancet, 1991, 337, 268-9.

${ }^{161}$ Hamburg and Colllins, "The Path to Personalized Medicine."

${ }^{162}$ As Joan Fujimura and many others have pointed out, new modes of genetic affinity often align themselves with pre-existing categories, especially with 
notions of race and ethnicity. See: J.H. Fujimura, T. Duster, and R. Rajagopalan, "Introduction: Race, Genetics, and Disease: Questions of Evidence, Matters of Consequences," Soc. Stud. Sci., 2008, 28, 643-56; G.T.H. Ellison, R. Tutton, S.M. Outram, P. Martin, R. Ashcroft, and A. Smart, "An Interdisciplinary Perspective on the Impact of Genomics on the Meaning of 'Race,' and the Future Role of Racial Categories in Biomedical Research," in Staffan Müller-Wille and Hans-Jörg Rheinberger, eds., "Race and Genomics: Old Wine in New Bottles? Documents from a Transdisciplinary Discussion," NTM J. Hist. Sci. Tech. Med., 2008, 16, 36386; B.A. Koenig, S.S.J. Lee, and S.S. Richardson, Revisiting Race in a Genomic Age (Piscataway, NJ: Rutgers University Press, 2008); I. Whitmarsh and D.S. Jones, What's the Use of Race: Modern Governance and the Biology of Difference (Cambridge: MIT Press, 2010). Race is so entrenched in modern genomics that it persists even when scientists develop special techniques to purge it from their analyses. See J.H. Fujimura and R. Rajagopalan, "Different Differences: The Use of 'Genetic Ancestry' versus Race in Biomedical Human Genetic Research," Soc. Stud. Sci., 2011, 41, 5-30.

${ }^{163}$ A.J. Wood, "Racial Differences in the Response to Drugs--Pointers to Genetic Differences," N. Engl. J. Med., 2001, 344, 1394-6. For a discussion, see Jones and Perlis, "Pharmacogenetics, Race, and Psychiatry." ${ }^{164}$ Gregory M. Dorr and David S. Jones, "Introduction: Facts and Fictions: BiDil and the Resurgence of Racial Medicine," J. Law, Med. Ethics, 2008, 36, 4438; G.T.H. Ellison, J.S. Kaufman, R.F. Head, P.A. Martin, and J.D. Kahn, "Flaws in 
the U.S. Food and Drug Administration's Rationale for Supporting the Development and Approval of BiDil as a Treatment for Heart Failure Only in Black Patients," J. Law, Med. Ethics, 2008, 36, 449-57.

165 J. Kahn, “How a Drug Becomes 'Ethnic': Law, Commerce, and the Production of Racial Categories in Medicine," Yale J. Health Policy Law Ethics, 2004, 4, 1-46; Kahn, "Race-ing Patents / Patenting Race: An Emerging Political Geography of Intellectual Property in Biotechnology," lowa Law Rev., 2007, 92, $353-416$.

${ }^{166}$ A. Pollock, Medicating Race: Heart Disease and Durable Preoccupations with Difference, Ph.D. dissertation, MIT, 2007; Pollock, "Reading Friedan: Toward a Feminist Articulation of Heart Disease," Body \& Society, 2010, 16, 77-97.

${ }^{167}$ As Kahn has explained: "Researchers and affiliated commercial enterprises are coming to see social categories of race as presenting opportunities for gaining, extending, or protecting monopoly market protection for an array of biotechnological products and services." See Kahn, "Race-ing Patents," 355.

${ }^{168}$ I. Whitmarsh and D.S. Jones, "Governance and the Uses of Race," in What's the Use of Race? Modern Governance and the Biology of Difference (Cambridge: MIT Press, 2010), 1-23, 1.

${ }^{169}$ See Nelkin and Lindee, The DNA Mystique. See also: Rabinow, "Artificiality and Enlightenment"; Rose, The Politics of Life Itself; Rose, "Race, Risk and Medicine in the Age 'Your Own Personal Genome,'" BioSocieties, 2008, 3, 423-39. 
${ }^{170}$ Hedgecoe and Martin, "The Drugs Don't Work"; Hedgecoe, The Politics of Personalized Medicine; Hedgecoe, "Pharmacogenetics as Alien Science: Alzheimer's Disease, Core Sets, and Expectations," Soc. Stud. Sci., 2006, 36, 723 52; Hedgecoe, "From Resistance to Usefulness: Sociology and the Clinical Uses of Genetic Tests," BioSocieties, 2008, 3, 183-94.

${ }^{171}$ Fujimura and others, "Introduction."

172 Hedgecoe and Martin, "The Drugs Don't Work"; Stevens, "Racial Meanings and Scientific Methods"; M. Fortun, Promising Genomics: Iceland and deCODE Genetics in a World of Speculation (Berkeley: University of California Press, 2008).

${ }^{173}$ See note 162 .

${ }^{174}$ S. Satel, "I Am a Racial Profiling Doctor: Illness Isn't Colorblind, So Why Is It Taboo for Doctors to take Note of a Patient's Race?" New York Times Magazine, 5 May 2002, 56-8. For a critique, Jones, "Racial Profiling in Psychiatry: Does It Help Patients?" Psychiatr. Times, 2006 (December), 23, 43.

${ }^{175}$ T. Duster, "Race and Reification in Science," Science, 2005, 307, 10501; Duster, "The Molecular Reinscription of Race: Unanticipated Issues in Biotechnology and Forensic Science," Patterns of Prejudice, 2006, 40, 427-41.

${ }^{176}$ D. Fullwiley, "Race and Genetics: Attempts to Define the Relationship," BioSocieties, 2007, 2, 221-37. The appeal of race is pervasive. Writing in 2001, Foster, Sharp, and Mulvilhill critiqued the move from personalized medicine to racialized medicine but continued to advocate for the use of pedigrees as an object 
of study despite their racial and ethnic baggage. See M.W. Foster, R.R. Sharp, and J.J. Mulvihill, "Pharmacogenetics, Race, and Ethnicity: Social Identities and Individualized Medical Care," Ther. Drug Monit., 2001, 23, 232-8.

${ }^{177}$ For examples, see: M.G. Bloche, "Race-based Therapeutics," N. Engl. J. Med., 2004, 351, 2035-7; Phimister, "Medicine and the Racial Divide." For discussions of this hope, see: Jones and Perlis, "Pharmacogenetics, Race, and Psychiatry"; R. Tutton, A. Smart, P. Martin, R. Ashcroft, and G.T.H. Ellison, “Genotyping the Future: Scientists' Expectations of Race/Ethnicity and Genetics After BiDil@," J. Law Med. Ethics, 2008, 36, 464-470.

${ }^{178}$ O.K. Obasogie, "Beyond Best Practices: Strict Scrutiny as a Regulatory Model for Race-Specific Medicines," J. Law Med. Ethics, 2008, 36, 491-497.

${ }^{179}$ Once inter-individual variability in drug response was classified as genetic or environmental, funds and effort were expended to flesh out the categories -- classifying is not just stamp-collecting, but something with real consequences on science. See G.C. Bowker and S.L. Star, Sorting Things Out: Classification and Its Consequences. (Cambridge: MIT Press, 1999). Interest in genetics intensified interest in pharmacogenetics, generating more research, more findings, and then more funding, a looping effect of sorts. See I. Hacking, "The Looping Effect of Human Kinds," in D. Sperber, D. Premack, and A.J. Premac, eds., Causal Cognition: An Interdisciplinary Approach (Oxford: Oxford University Press, 1995). 
${ }^{180}$ H.L. Behforouz, P.E. Farmer, and J. Mukherjee, "From Directly Observed Therapy to Accompagnateurs: Enhancing AIDS Treatment Outcomes in Haiti and in Boston," Clin. Infect. Dis., 2004, 38 (supplement 5), S429-S436.

${ }^{181}$ N. Wade, "Decades Later, Genetic Map Yields Few Cures," New York

Times, 12 June 2010.

${ }^{182}$ Motulsky, quoted in Driefus, "A Genetics Pioneer See a Bright Future, Cautiously." 